\title{
THE LARGER TORAJAN WORLD MIGRANT NETWORKS AND ORGANIZATIONS
}

In the Introduction we saw that a significant proportion of Torajans live outside the highlands - elsewhere in Indonesia or abroad. Given that people are migrating back and forth, the Torajan world cannot be found at a single location. So what exactly is the Torajan world like, and where can we find it? In this chapter, the focus will be particularly on that part of the Torajan world that exists beyond the borders of Tana Toraja, that is, the migrant community. To come to grips with such a complex and broad phenomenon as the Torajan migrant world, I have divided this chapter into three sections. The first section provides a general overview of the origins of the Torajan migrant community and describes the outcomes of the considerable twentieth-century 'exodus'. More specifically, it provides insights into the direction, characteristics and scale of migration, and the way in which these migrants have created migrant communities at various places of settlement. Although some authors have hinted at the migratory ways of Torajans, a thorough systematic account of the history of Torajan migration is lacking. Therefore, alongside providing a description of the historical making of the Torajan transnational community as an essential element in moving toward an answer to the central research question, this section also aims to contribute to the general historical understanding of Tana Toraja with new perspectives drawn from archival research.

In the second section, the focus is more on the similarities and differences between the various migrant communities or diasporas, the relationships between these communities and their host populations, and the extent to which this whole process has resulted in a large Torajan social space. Along with the overall data, I present several examples of diasporic communities that reflect great internal variations. After having concluded that the Torajan world has become larger and widely spread, and that it includes both the heartland of Tana Toraja and the migrant diaspora, the third section provides a case study of one of these diasporas, namely Makassar. This city is a node in the Torajan world where people maintain both forward and backward relationships. The case study provides a differentiated picture of the ways in which Torajans live and work in an urban

(C) EDWIN DE JONG, 2013 | DOI 10.1163/9789004252479_004

This is an open access chapter distributed under the terms of the CC-BY-NC-ND License. 
migrant community. Makassar is the home of the largest Torajan community outside of Tana Toraja, one of the oldest urban destinations for Torajan migrants, and fulfils a central role in the translocal Torajan network through its geographical location. Thus it makes the Torajan transmigrant community in Makassar not only an obvious, but also a pivotal case to study.

\section{Torajans on the Move}

Among the various Indonesian peoples, migration is certainly not a recent phenomenon. The Minangkabau of West Sumatra are probably bestknown for their long history of migration to obtain worldly wisdom, experience and wealth (Volkman 1985:157). The Indonesian word for migration, 'merantau', is even adopted from the Minangkabau word rantau, literally meaning coastal- or outer-area (Persoon 1983:215). Also, on the island of Sulawesi, the Bugis inhabiting the southern coastal areas are well-known as great seafarers who sailed and settled as far away as West Malaysia in the sixteenth century. ${ }^{1}$ Their highland neighbours on the other hand, the Torajan people, have historically not shown any particular propensity to migrate. In fact, as Volkman (1985:132) argues, the contrary is the case: ' $[\mathrm{H}]$ ighlanders traditionally shunned unnecessary movement, preferring to stay close to their significant centers: the tongkonan, the place of the umbilical cords'.

Notwithstanding this inward force, the end of the nineteenth century saw the beginning of out-migration that gained momentum in the late 1960s when the majority of Torajan migrants left their homeland. Apart from the much greater numbers of migrants, the direction, objectives and periods of migration have changed significantly since the 196os. It has become common to speak of 'before merantau' to refer to the period before the 196os, when travelling was often dangerous because of political tensions and brigandage, and 'after merantau', which concerns the period since, when peace returned to the region and opportunities for wage labour outside the region increased (Volkman 1984:158). In the following two sections, I discuss the history of Torajan migration in these two broad periods to emphasize the profound changes that have occurred since the 1960 s.

1 In addition, the Bugis travelled to other places over land. For accounts on Bugis migration within South Sulawesi, see for example Acciaioli 2000, 2004; Lineton 1975. 


\section{Before merantau}

Although some Torajans would occasionally leave the highlands in the distant past, the first significant flow of albeit forced migration took place when thousands of highlanders were captured as slaves and sold to the Bugis in the lowlands (Bigalke 1981). Historical descriptions by a French missionary that date from 1660 and of two Swiss ethnographers drawn up in 1895 already refer to the transportation of Torajan slaves to Thailand and Malaysia. However, the peak of this slave trade occurred at the end of the nineteenth century (Bigalke 1983). As many as 12,000 Torajans are estimated to have been seized and transported for sale as slaves to the lowlands of South Sulawesi (Bigalke 1981:141). As in other Southeast Asian societies, the enslavement of Torajans was essentially intended to meet the labour shortage in a conquering neighbouring kingdom. However, '[w] hat makes the Torajan case rather unusual in view of the generally accepted interpretation of the underlying purpose of slavery in Southeast Asia is the apparent readiness of so many chiefs to reduce the Torajan population rather than concentrate it for their own political and economic benefits' (Bigalke 1983:352). Probably due to this readiness of their masters to sell them to Bugis traders, as well as to their subsequent integration into lowland life, that only about one-third of the total number of Torajans exported as slaves returned to the highlands after the Dutch colonial government, in 1911, officially abolished slavery in the highlands and allowed Torajans to legally return from the Bugis lowlands (Bigalke 1981:82, 141).

In the subsequent period, some Torajans left their homeland and went to Rongkong to the Northeast of Palopo where they converted uncultivated land into sawah (wet rice-fields), worked in the nickel mines of Malili along the Gulf of Bone, or gathered damar (resin) in the forests of Malili. ${ }^{2}$ Nevertheless, as of 1920, most people still rarely left their villages, and any migration was mainly on a seasonal or short-term basis. In the mid-1920s, all-weather roads to Pare Pare in the south (1923) and Palopo in the east (1927) were finally completed thus connecting Tana Toraja with the 'outside world' (Van Lijf 1952-1953:254). Van der Veen had already witnessed the 'earliest stage of 'modern" out-migration' in 1921, 'when he saw Torajan policemen on the streets of Makassar' (Bigalke 1981:197). The newly-built roads brought the cities of Palopo, Pare Pare and areas further from Makassar effectively much closer to the highlands and signified the real beginning of the 'modern era' of Torajan out-migration.

2 Van der End 1985:120; Bigalke 1981:474. For the migration patterns during the 'before merantau' period, see Map 3.1. 
The introduction of a head tax by the Dutch administration in the mid1920 led to an increased need for money and forced even more Torajans to leave their homeland. Thousands of people swarmed out of the denselypopulated highlands to other places in Sulawesi where they could find employment. In the late 1920 s and early 1930s, the first Torajan urban communities started to be seen in the ports of Palopo, Makassar and Pare Pare (Van der End 1985:288; Plaisier 1993:92). In 1929, Van der Veen was also reporting the existence of various migrant settlements in the district of Luwu, in both the mountainous regions as well as on the plains. Further, Torajans established communities on the coast of Dongalla, at the large

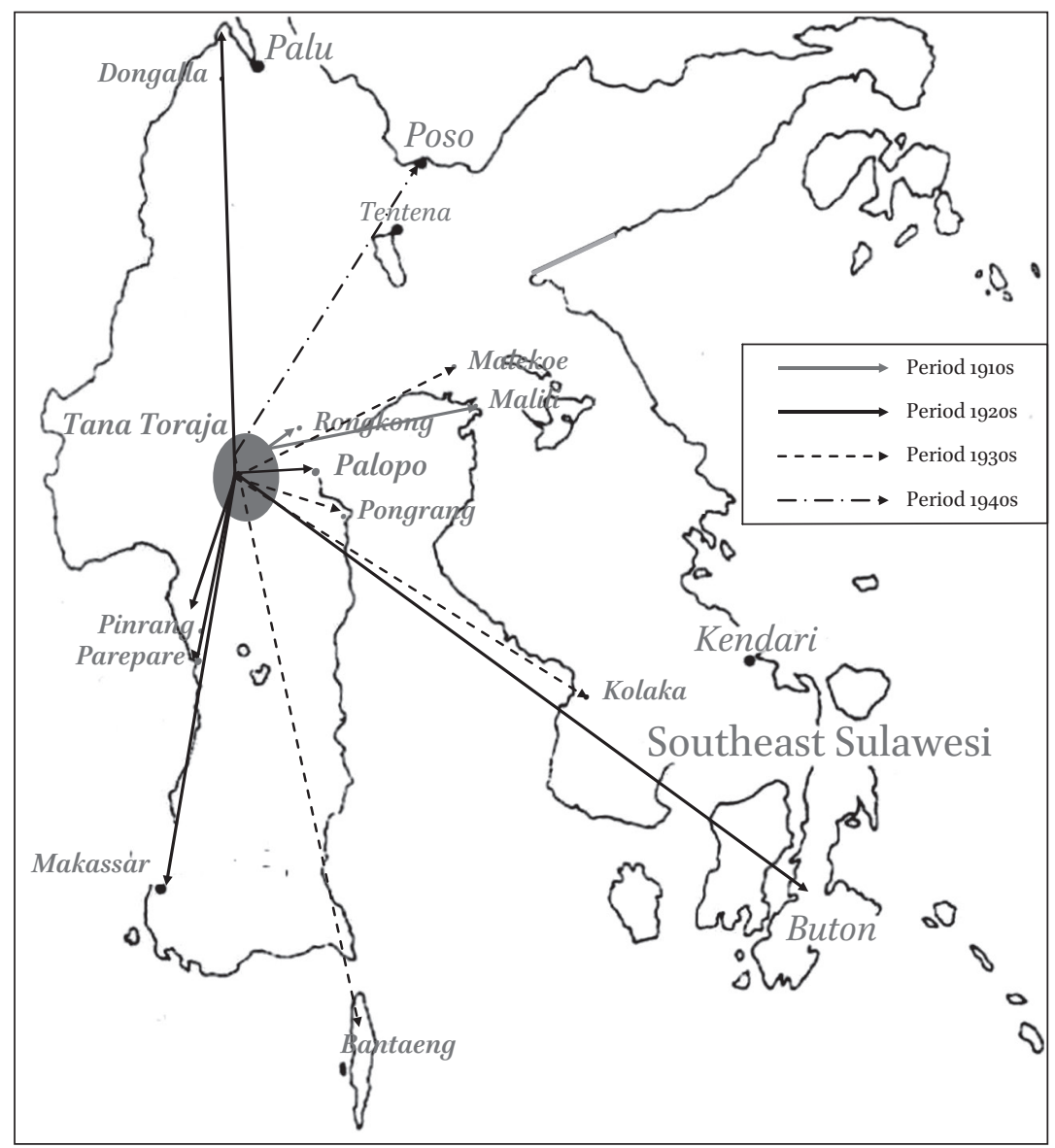

Map 3.1. Migration routes of Torajans with dates of commencement. Source: Map by Edwin de Jong. 
irrigation projects in Pinrang, and at the asphalt exploitation works on the island of Buton, to the south of Sulawesi. ${ }^{3}$

This flow of migration that had got underway in a little more than a decade received an enormous boost in the late 1930s when the 'Great Depression' hit the highlands. 'By then the bottom had fallen out of the coffee market and people were having to struggle to come up with cash for taxes. The cash crunch got more severe into the late 1930s, stimulating large scale out-migration of youths to highland areas rich in forest products (northern Luwu afdeeling), to lowland public works projects, and to regional cities' (Bigalke 1981:254). Many people felt compelled to leave their villages for a year or more to earn cash to pay their families' taxes. The number of people leaving their villages approached the number of forced 'out-migrants' during the slave trade days. Torajan men generally found employment at Bantaeng, Malili, Kolaka, Pare Pare or elsewhere in Sulawesi, and women mainly worked in factories or for Chinese traders in urban areas such as Pare Pare and Makassar. The account by Pol, a missionary in the southern part of Tana Toraja in 1938, well illustrates the enormous dimension of this migration flow:

In many places the harvest has failed for several years in a row. By necessity, men are spreading far and wide to earn money to pay their taxes. Regular church attendance is also suffering from this. For weeks at a time they leave home and often return with malaria, through which they are restricted to their homes and not able to visit church. More than half of the population in the parish of Tokesan has moved to the forests of Malili and Kolaka. The people of Batoealoe are joining this move. Some are leaving to Malili and Kolaka but others are settling down on the coastal plains of Ponrang, where it is supposedly easier to make a living. This transmigration is raising unanswered questions for this parish. In Malili and Kolaka these are no Christian communities, which these people might join. In the forests they are very dispersed, or they are temporarily moving in with Mohammedans inhabiting the coastal plains. How to spiritually look after these absent people? I was pleasantly surprised to hear one of these days that, at Malekoe near Malili, a place where hundreds of Torajans are living including several Christians, they were organising a service themselves every Sunday. ...It is impossible for the mission to take care of all the places where Torajans are moving to. (Van den End 1985:427.)

Moreover, Bigalke (1981:257-8) noted that the Torajan migration to the city of Makassar had 'grown somewhere between 3 to 5 times, in the four

3 F.J. Ormeling, 'Toradja's', 1948, p. 12, in: KITLV, Collectie F.J. Ormeling, D H 1132; Van der End 1985:288; Plaisier 1993:92. 
depressed years after $19355^{4}$ Among the female migrants were probably the first Torajan prostitutes to appear in Makassar. Also in this period the first Torajan youth moved to Palopo, Pare Pare, Makassar and some cities in Java for education needed to join the police force or for a position in the 'lower echelons of the colonial service' (Bigalke 1981:267).

During the years of the Japanese occupation, between 1942 and 1945, many Torajans were forced to work on the road from Wotu (at the northern tip of the Gulf of Bone) to Poso. There, and at other infrastructural projects in the lowlands, many died of malnutrition and bad treatment, while thousands of others returned heavily affected by malaria to their highland villages (Van Lijf 1951:259). In the immediate years after the Pacific War, Tana Toraja needed to recover from the problems caused by the Japanese occupation, and an increasing number of migrants left the highlands in search of a living, or to pay off debts caused through gambling, the organization of ceremonial activities, or to arrange an appropriate marriage. The Torajan community in Makassar had already grown to as many as 5,000 (two percent) of the 210,000 Torajans living in Tana Toraja. They were working mostly as domestic servants or entrepreneurs, as officials at government bureaus, or as labourers in the wood-processing and furniture industries and in shoe factories (Van Lijf 1947:62; Heeren 1952). According to Ormeling, ${ }^{5}$ most Torajan migrants were doing surprisingly well in the city because of their mutual relations and reciprocal help. Their solidarity was strengthened by the contrasts between Torajans and other ethnic groups, especially the Bugis. The fact that most Torajans were Christian or considered to be non-believers (pagans) among a predominantly Islamic population, also set them apart and as a consequence reinforced their mutual ties in the diaspora.

For many Torajans, the city had no enduring attraction, and most of them returned to Tana Toraja once they had earned enough money to buy back their pawned rice fields, paid off debts incurred at past ceremonies or entered into new debt relationships through organizing a ceremony for deceased relatives (Heeren 1952:62). Important reasons, or push factors, for migration were cash shortages, debts and obligations related to death rituals, or gambling, forms of bondage, other conflicts, land shortages and the lack of higher education in the area.

${ }^{4}$ In 1935, between 500 and 700 Torajans were living in Makassar, a number which had increased to 3000 by 1939 (Roeroek 1939). This figure also includes Torajans from the region of Mamasa, but most Torajans were from the subregion of Makale-Rantepao, the contemporary district of Tana Toraja.

5 F.J. Ormeling, 'Toradja's', 1948, p. 12, in: KITLV, Collectie F.J. Ormeling, D H 1132. 
A number of the migrants were women working as prostitutes. Research by the Department of Social Welfare estimated that the total number of prostitutes in Makassar numbered 800 to 1000, of whom 60 percent were Torajan. ${ }^{6}$ According to Wijker, ${ }^{7}$ one would be wrong to ascribe the reasons for the high number of Torajan prostitutes in Makassar solely to poor economic conditions in Tana Toraja. Rather, the 'loose character' of Torajans was postulated as the principal rationale for their 'moral straying' by Wijker and his research team. ${ }^{8}$ Lobo and Nooy-Palm (1978:ii) came up with a more nuanced reason, which they based on a prostitution report of that time..$^{9}$ They wrote that Torajan women worked only temporarily in prostitution to save enough money for their bride wealth, which was needed for their future marriage in Tana Toraja.

Even though this era is marked by increasing migration, the majority of Torajans stayed put in the highlands. Kennedy (1953:178) noted that, as of 1949, most Torajans had hardly ever left their village. By using the example of a settlement about five kilometres from Rantepao, he estimated 'that 80 percent of the women and 20 percent of the men had never visited the capital Makale (less than twenty kilometres away), that less than 5 percent of the villagers had ever left the district, and that far less than 1 percent had ever left the island [of Sulawesi]' (Kennedy 1953 in Volkman 1985:133-4).

Migration at that time became a reality only for people from a small number of villages. Generally, travelling was difficult and Torajans found it hard to establish a new life in a strange and unknown world. Most people only migrated when they already knew some Torajans at the place of destination. When no relatives or acquaintances were around, they were generally taken care of by other Torajan migrants. Thus Torajan migration could be characterized as a form of chain migration, through which wellknit migrant communities gradually came into being. For example, Pa'Pongtiku, who came from a village in the north of Tana Toraja, left for Jakarta in the early 1950 s to work as a military official. When he arrived in

6 W. Wijker, 'Nota naar aanleiding van een onderzoek naar de prostitutie te Makassar', 1948, in: Nationaal Archief, Den Haag, Ministerie van Koloniën: Memories van Overgave, 1852-1962, nummer toegang 2.10.39, inventarisnummer 1113 .

7 W. Wijker, 'Nota naar aanleiding van een onderzoek naar de prostitutie te Makassar', 1948, p. 6, in: Nationaal Archief, Den Haag, Ministerie van Koloniën: Memories van Overgave, 1852-1962, nummer toegang 2.10.39, inventarisnummer 1113.

8 W. Wijker, 'Nota naar aanleiding van een onderzoek naar de prostitutie te Makassar', 1948, p. 8, in: Nationaal Archief, Den Haag, Ministerie van Koloniën: Memories van Overgave, 1852-1962, nummer toegang 2.10.39, inventarisnummer 1113 .

9 The origin and title and exact date of the report are not specified. 
Jakarta he stayed at the house of Pa'Sarungalo, the first Torajan ever to become a lawyer (after obtaining a degree in the Netherlands). 'Even outside Tana Toraja, Torajans try to keep in touch with one another (with the migrant community)' Pa'Pongtiku said. 'When Torajan people arrived at Tanjung Priok harbour in Jakarta, Pa'Sarungalo picked them up and gave them some money in exchange for information about Tana Toraja. Torajan intellectuals in Jakarta such as Pa'Sarungalo felt responsible for the wellbeing of the Torajan community and offered newcomers assistance upon arrival. Torajans were close to each other in Jakarta, as strangers in an unknown world who sought support among their own. To further stimulate the Torajan network in Jakarta, several notable Torajans established the organization Kekeluargaan Masyarakat Toraja (KMT), whose main purpose was to solve basic problems faced by newcomers: finding a job and a place to stay. Further, it provided assistance to members who lost relatives, even if the forthcoming funeral ceremony was planned far in advance. The KMT also stimulated the establishment of the Kerukunan Keluarga Sulawesi Selatan (KKSS). This organization involves all people from South Sulawesi: Bugis, Mandarese, Makassarese, and Torajans. However, the KKSS only provided assistance in the event of emergencies, and not for forthcoming ceremonies.

Land pressure in Tana Toraja was greater than in most of South Sulawesi and the expansion of agriculture had reached its limits. 'Aggravating this situation was the way in which prominent families maintained their hold on large tracts of land accumulated over generations, which they never sold, and which marrying within the family (as close as first cousins) helped to maintain intact' (Bigalke 1981:399). Aware of the potential social conflict over land, in September 1949 the minister of the regional government, some civil servants from Jakarta and Makassar, local administrators, representatives of the Protestant and Catholic missions and some private individuals, discussed the possibility of transmigrating several tens of thousands of Torajans to sparsely populated regions in and around the highlands (Van Lijf 1952-1953:274). After the collapse of the State of East Indonesia in 1950, however, they were unable to turn these plans into actions.

Nevertheless, the issue of transmigration re-emerged in $195^{\circ}$ under the Emergency Government (Pemerintahan Darurat) of Indonesia, leading to the establishment of a Committee for Local Transmigration (Panitia Locale Transmigrasi Kabupaten Luwu) in $1951 .{ }^{10}$ The Committee,

10 ANUP-Tator, in: Arsip Nasional Indonesia Ujung Pandang, 1359. 
consisting both of Torajan and Luwu representatives drew up a plan for mass migration of Torajans to the Luwu region - the areas of Walenrang and Masamba to the north of Palopo'. A report of a meeting of this Committee suggested that 20,000 Torajan households-in other words, half of all Torajan households involved in farming - should be moved to the neighbouring area of Luwu. ${ }^{11}$ However, again these plans could not be further elaborated because, by 1952, Muslim guerrilla groups from Luwu were starting to attack the southern and eastern peripheries of Tana Toraja. Bigalke (1981:423) noted that at that time " $\mathrm{t}]$ here were numerous abductions, killings, thefts, and incidents where villages [with their traditional tongkonan houses] were burnt'.

The guerrilla raids coincided with the Darul Islam rebellion (DI/TII, aiming to establish an Islamic State in Indonesia) that started in 1953 under the leadership of Kahar Muhzakkar and swept through South Sulawesi. The prominence of Kahar Muhzakkar and his guerrilla attacks made travelling throughout South Sulawesi extremely difficult. Pa' Sudenden who had registered at the police academy in Makassar at that time told me that he went to Makassar in a convoy of twenty cars with plenty of people. They had to frequently pause at places where guerrilla attacks from Kahar Muhzakkar could be expected to make sure that everything was safe. The trip took a full week. While contact with the highlands seemed difficult at that time, the 'outside world' nevertheless offered a completely new experience. During subsequent years of rebellion, the small Torajan migrant flow that had got under way came almost to a standstill until 1965 when Suharto's 'New Order' army defeated Kahar Muhzakkar's troops and peace returned to the highlands.

In the early 1960s, the district heads representing Tana Toraja and Luwu reached an agreement about the regulated and controlled migration of a large number of Torajan farmers to Luwu (Roth 2003:82-3): 'Torajan officials were still prominently present in the Luwu government offices and, through their administrative positions, formed a strong power block in favour of local transmigration'. The good educational system in Tana Toraja had enabled many Torajans to find employment in the Luwu offices during the 1950s. 'Tana Toraja possesses the finest educational system in all of rural South Sulawesi. Developed over half a century by missionaries, Toraja Protestant and Catholic schools have produced high caliber high schools and technical school graduates whose skills have been utilized in

11 ANUP-Tator, in: Arsip Nasional Indonesia Ujung Pandang, 1361. 
government service, the armed forces, and private industry' (Crystal 1989:165).

The volume of transmigration, as well as statements about boundaries and identities, were settled in the so-called Makula agreement, named after a village in Tana Toraja where the meeting was held. ${ }^{12}$ 'There was a general feeling that development of Luwu required a higher population density, preferably provided by Toraja farmers..... Their settlement in Luwu, then, was not seen as problematic, but rather as a stimulus for the development of relatively isolated Luwu.' (Roth 2003:83.) The Makula agreement marked the beginning of local transmigration from Tana Toraja to the Luwu plain, which unfolded in two ways: ' $[\mathrm{O}] \mathrm{n}$ the one hand there was the migration and settlement officially recognized and regulated by the Luwu and Toraja administrations. On the other hand, to an increasing extent migration and settlement took place outside of the scope of the formal agreement.' (Roth 2003: 83.) With regard to the formally regulated and controlled migration and settlement, it was initially not easy to find candidates because of the recurrent guerrilla attacks on Torajan settlements in Luwu. Moreover, many Torajans still associated migration with poverty and low social status, and those within the lower social echelons still followed their leaders; leaving without them was out of the question. Although the planned large-scale transmigration did not really take off in this period, hundreds of Torajans did move to Luwu and, today, several settlements in lowland Luwu are still directly or indirectly associated with the Makula agreement (Roth 2003:83).

To summarize, during 60 years of external interference in the highlands, there have been several considerable migration streams. These streams were partly the result of internal measures such as, under the Dutch, when the head tax was introduced, or under the Japanese, when many highlanders were forced to work at specific infrastructure projects in the lowlands. Also the increasing land pressures and food shortages drove Torajans away from the highlands. Migration was also the result of international economic crises, but most importantly it was a reaction to changing needs and opportunities. With the introduction of an educational system, people desired higher education that could only be found beyond the highlands. With the introduction of money, people left the highlands to find better paid jobs. Moreover, the growing and industrializing cities of Pare

12 Because the Makula agreement 'is not documented in the archives of the Luwu or Tana Toraja administrations any longer', many details remain unclear (Roth 2003:82). 
Pare, Palopo' and Makassar became more attractive, and, most importantly, infrastructure improvements made travelling away from the highlands easier.

\section{After merantau}

Although there was an increased displacement of Torajans once the Dutch entered Tana Toraja in the early twentieth century, for most people migration remained a rare phenomenon until the late 1960 s when the 'after merantau' period started. After the final defeat of the Darul Islam revolt, repair work to demolished bridges and roadways slowly began (Crystal 1974:148-9). Although roads to and from Tana Toraja were still frequently impassable due to mud and rock slides in the late-196os, this period marked the beginning of an unprecedented migration stream. Increasingly large numbers of farmers now moved to areas in Luwu, such as Batusitanduk and Lamasi, to open up vast new rice lands. As Roth (2003:86) noted,after the Makula agreement had been mothballed...Luwu was flooded with what was called transmigrasi gelap (illicit transmigration), a process that could not be regulated, even less stopped. Increasingly, people came to Luwu on their own initiative. After having sold a parcel of land, buffalo or other possessions in Tana Toraja, they took the proceeds to the Luwu plain and invested in cheap and widely available land.' Interestingly, Torajan migrants established themselves in or close to existing settlements, whereas the national transmigration programme had designated new sites away from local villages for the migrants primarily from Java, Bali, Lombok and Nusa Tenggara Timur (International Crisis Group 2003:8).

Torajan migration to the city of Makassar, already in favour for many decades, albeit with some downturn during the 1952-1965 period, continued at a steady pace, and by 1971 they numbered some 50,000-about ten percent of the city's population (Nooy-Palm et al. 1979b:2). The nickel mining industry at Malili and Soroako in the eastern part of Luwu became another popular destination for Torajan migrants when the Indonesian government granted a contract to International Nickel of Canada (PT Inco) to exploit the nickel deposit in the Luwu region. 'In Saroako for example, Torajan migrants made up about 40 per cent of the unskilled labourers working for PT Inco by 1978' (Robinson 1986:39). Besides these roughly 900 labourers, a few hundred Torajans were working as domestic servants in the mining town. Interestingly, most Torajans were not living in the town itself but in the village of Wawandula, which had become a 
predominantly Torajan settlement and is located just south of the mining project. In 1978, the decision by the government's agricultural extension service to nominate Palopo as a cacao production centre set the stage for what is locally called the Torajan (and Bugis) invasion of North Luwu (ICG 2003:8). By the mid-199os, however, the plain of Luwu had become less attractive for new settlers, and the flow of Torajan migrants moved northwards to Central and North Sulawesi.

While a steady stream of Torajan settlers was spreading out over Sulawesi, the horizons of many Torajans also began to expand. By the late 1960s, President Suharto opened Jakarta's doors to foreign investment on Indonesian soil, and multinational corporations established themselves in Kalimantan, Irian Jaya, Central Sulawesi and elsewhere to exploit the natural resources of the Indonesian archipelago (Volkman 1985:135). 'The underemployed, educated, and highly motivated young Toraja wanted jobs. They rejected subsistence agriculture at home for at least two reasons: it could not support their physical needs; it lacked the enticements of a "modern" life with cash, cities, watches, radios, blue jeans, and Elvis Presley tapes. For former slaves or persons at the bottom of the status hierarchy, migration also offered a chance to acquire previously undreamed of wealth and prestige' (Volkman 1985). Since then, many more Torajan settlers have moved beyond the borders of Sulawesi, and the seeds for the contemporary nationwide and even global Torajan migrant community have been sown. As Volkman (1980:36) phrases it appropriately, 'Toraja cannot be understood in Sulawesian terms alone, for its universe has expanded to include at least Java, Borneo, Bali, and Irian Jaya'.

Initially, Torajans sailed across the Makassar Straits to several places in East Kalimantan (Balikpapan, Nunukan and Samarinda) and West Kalimantan (Pontianak) where they started working in the oilfields and for timber corporations. They undertook all kinds of work, such as 'felling trees, driving tractors, or as mechanics, while women would typically become cooks and housekeepers for foreign or wealthy families' (Volkman 1985:134). From Nunukan, at the northern tip of Kalimantan, they also started to cross the Indonesian border in search of work in the forests of East Malaysia (Sabah). Around go percent of them entered Malaysia illegally (imigrasi gelap) by sea and arrived at the harbour of Tawau where they were met by family, acquaintances or human traffickers (Mangoting 1997). While many were employed by the logging companies in the nearby forests or at large commercial agricultural enterprises, some moved on to other places in Sabah, such as Sandakan, Kinabalu and Keningau. Later, Torajans advanced to neighbouring Sarawak, the oil state of Brunei, and 
the western peninsula of Malaysia. Many Torajan men and women found factory work at the industrial areas that were rapidly developing in the eastern part of Malaysia.

Among these migrants were a great number of Torajan girls and women, some of whom ended up in the sex industry surrounding these industrial areas. As Mangoting (1997) notes, as early as the 1970s and 1980s, Torajan girls and women were lured to Malaysia to work as prostitutes, either under false pretences or by 'choice'. Many Torajan girls and women still end up in the sex business in eastern Malaysia.

Besides Kalimantan and Malaysia, Irian Jaya (today West Papua) became another popular destination when it was opened up for immigration in the early 1970s. Many Torajan economic migrants started to move there and penetrated deep into the jungles to work in the logging and sawmill industries. Moreover, thousands of Torajans, both those with little education and those highly educated, found employment at the Grasberg mine at Freeport, which was the largest gold mine, and third largest copper mine, in the world — or at one of the many other mines that opened up in Irian Jaya. Most Torajans settled along the border between Indonesia and Papua New Guinea, near the large towns of Jayapura and Merauke, or in the forestry and mining areas of Sorong and Timika.

Those who did not take the route to Kalimantan, East Malaysia, Sabah and Irian, were often children of Dutch-influenced, more prosperous families (Volkman 1985:134). They went instead to Makassar or one of the major Javanese cities, such as Jakarta, Bogor, Bandung and Surabaya, to obtain higher education. As a consequence, many of the Torajan migrants living in these cities work as businessmen, government officials, teachers or policemen. Thousands of other well-educated Torajans move to places elsewhere in Indonesia (primarily Ambon, East Timor and Bali) to take positions in government service. Since the 1990s, the number of Torajan migrants moving to Australia, North America, Europe and East Asia has also been on the increase. The most common reasons are for higher education, marriage to a foreigner, or simply employment. Hongkong, South Korea and Japan have attracted hundreds of Torajans for jobs in factories or as servants or nannies. These people are usually granted a temporary residence permit for a couple of years only. Batam is a destination within Indonesianthat has recently gained popularity among Torajan youngsters. Unmarried Torajan women between the ages of 15 and 25 can find employment in a large electronics factory.

Today, the number of Torajans leaving their homeland remains high as many of them are well-educated and unable to find suitable employment 
locally. Volkman (1985:134) already noted in 1978 through a small sampling of households in one area, that youngsters left the villages en masse: '[L] ess than $30 \%$ of 150 people between the ages of 15 and 35 remained in their village. Of those who remained, some anticipated leaving when they finished high school; some had previously been to Kalimantan and had plans to return.' Not much seems to have changed since. Today, the Torajan diaspora, estimated at 650,000 , exceeds the highland population $(458,000)$ by fifty per cent. ${ }^{13}$

\section{The Torajan Migrant World after 2000}

As we have seen from the preceding paragraphs, the contemporary characteristics of the Torajan diaspora have been shaped by local, national and international developments. Until the 196os, Torajan migration generally was aimed at agricultural activities in the sparsely populated areas of Sulawesi. This process resulted in settlements of farmers, some composed solely of Torajans, others consisting of mixed migrant groups (Torajan, Bugis, resettled locals and Javanese). Although these agricultural communities still make up a considerable share of the total diaspora, the changing nature and direction of migration has added to the variety of Torajan diasporas that have emerged at various places within and beyond Indonesia. Notwithstanding these differences, they share common characteristics, such as ways of organization, places of encounter, and networking characteristics that facilitate the movement of people, capital, goods and information. In what follows, I compare the contemporary diasporas in terms of geographic distribution, population size, composition and social density. Alongside the overall data, I will present several examples of diasporic communities that show great internal diversity.

13 The 2000 Indonesian Population Census indicates that there are a total of 750,828 Torajans (that is people from the Tana Toraja district) (Suryadinata et al. 2003:7). This means that around 350,000 Torajans live outside Tana Toraja according to official accounts. In reality, the number will be much higher if we were to include the registered and nonregistered migrants and commuters in Indonesia, and the Torajans who live overseas. Aleksander Mangoting, who conducted research among Torajan illegal immigrants in Malaysia, estimated that about 50,00o Torajans reside in Malaysia (Mangoting 1997). The Reformed Ecumenical Council (REC) speaks of about 300,000 Torajans who have gone to Malaysia as migrants, mostly on quasi-legal arrangements (Van Houten 2003). Although the latter figure seems somewhat exaggerated, according to Torajan informants who have returned home from all over the world to attend funeral ceremonies, tens of thousands of Torajans do live in Malaysia, South and Southeast Asia, Europe, Australia and North America. 
It is nearly impossible to find accurate figures on the size of the Torajan migrant population because reliable statistics do not exist and not all migrants are permanent settlers but instead commute or move from one place to another. Further, a fair number of migrants are illegal settlers and therefore not registered with the local administration. However, we can approximate the size of the larger diasporas using information from the Torajan church, through migrant organizations (kerukunan) and from personal interviews with migrants living at a particular place or who regularly travel around to meet other Torajans for business or other reasons. Since over 90 percent of Torajan migrants live in Southeast Asia, figures are shown for this region only (see Map 3.2).

Outside Southeast Asia there are also Torajan communities in the making, most notably in Hongkong, South Korea, Japan, Australia, the Netherlands, Belgium, Germany and the United States. The sizes of these communities vary from a few hundred to several thousand.

Map 3.2 shows that the communities in Makassar and Luwu are clearly the largest and, in this respect, there has not been much proportional change in the Torajan diaspora 'after merantau' in the late 1960s. However, what is new is the mushrooming of Torajan migrant communities outside Sulawesi and Java in the last two decades. Moreover, most, if not all, diaspora display considerable internal differences in composition, settlement

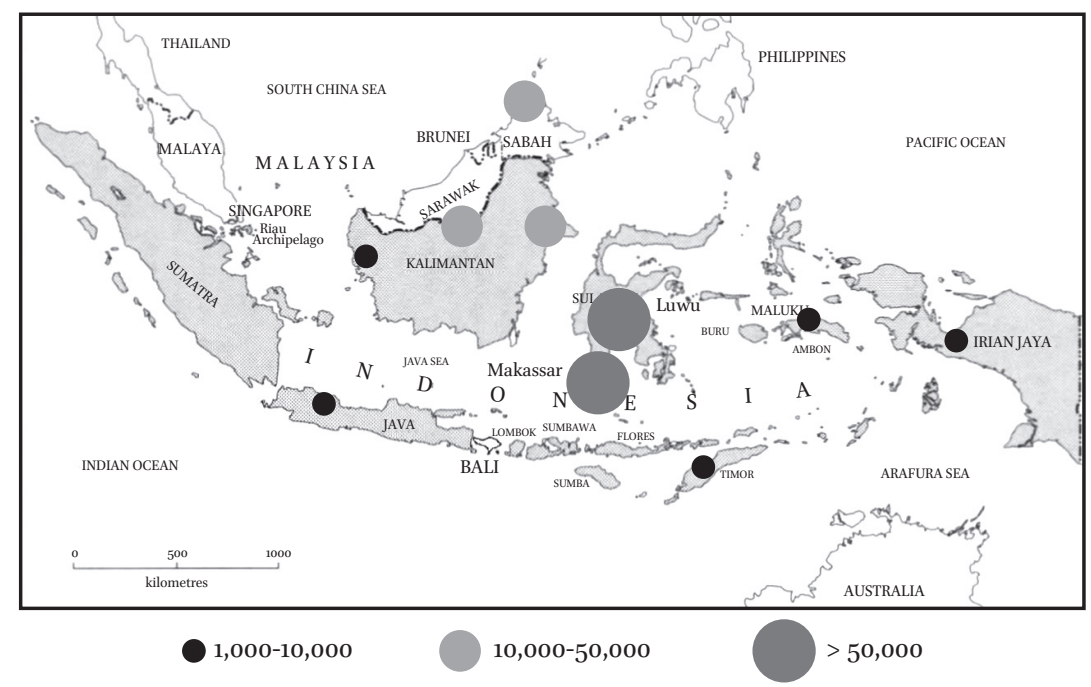

Map 3.2. Distribution of Torajans across Southeast Asia (2003). Source: Map based on city layout from Forbes (1979:5). 
patterns, economic activities and organization. In what follows, I present two contrasting examples of transmigrant communities that differ in all these attributes: one is in east Malaysia and one in Jakarta.

\section{Different Settings, Same Outcome: Two Torajan Diasporas Compared}

In Tawau district, the most easterly part of Malaysia (in the province of Sabah), lies Batu Dua, or Hilltop village, where almost all Torajans in Tawau live. Their community adds up to about 1,0oo households, nearly all originating from the lowest social class in their homeland (Mangoting 1997:51). The vast majority entered Malaysia by sea and arrived at the harbour of Tawau,after about two days and two nights of travel. ${ }^{14}$ Most of those staying here are illegal migrants who live by growing vegetables for market or working on the nearby cocoa plantations. Unlike in most other Torajan communities in Malaysia, none of the women in the community work as prostitutes; several years ago a group of elders successfully fought for a prohibition against participation in the sex industry. ${ }^{15}$

Hilltop Village is a Protestant and Catholic enclave within a predominantly Muslim society with its own Protestant Torajan church. Torajans feel that life for them is harder in Malaysia because of their minority religion. As one of the migrants put it 'the Malaysian government does not want the people of Hilltop Village (mostly Torajans) to stay there because the land is owned by the king and he has plans to return all illegal migrants to Indonesia next year. Bugis people get official documents more easily because they are Muslim, and therefore have a better chance to survive here.' Without official residence permits, these migrants cannot find a permanent job and face being deported or arrested by the police at any moment. They send little money home to their families in Tana Toraja on a regular basis, claiming that incomes are not high enough to make ends meet. Mangoting (1997:65) noted that 95 per cent of the men take part in gambling and cock fighting. However, mutual support is strong; when someone needs money for the funeral ceremony of a deceased relative in Tana Toraja, or when someone gets seriously sick, other Torajans in Hilltop Village will raise money for him or her. They also have a formal organization (the so-called kerukunan) that functions as a mutual support system and also as a social framework to keep the migrant community together by

\footnotetext{
14 It takes four hours to get from Tana Toraja to the harbour of Pare Pare by bus, two days and one night by ferry from Pare Pare to Nunukan (located at the northern tip of East Kalimantan), and two more hours by ferry to Tawau, Malaysia.

15 It is not clear to me whether these elders are Torajans or Malaysians.
} 
organizing special meetings, most notably Christmas celebrations. These kerukunan are part of the IKAT (Ikat Keluarga Toraja) Sabah. The literal translation of ikatan is 'bundle', but it is better understood as a tie that binds, or even better as a union. Keluarga means family, and thus IKAT should be understood as the union of the Torajan family in Eastern Malaysia. The IKAT is an organization that generally operates on an overarching level. Its leaders try to strengthen the Torajan community in Sabah by organizing social gatherings and also through meetings in which particular problems within the migrant community as well as in Tana Toraja are discussed, and possible plans for action developed.

In Jakarta, the Torajan community has a longer and more sustainable history than the Hilltop Village diaspora. We saw a glimpse of the birth of the Torajan community in Jakarta in the preceding sections. The first Torajans came to Jakarta in the 1950 s for higher education or to work as government employees. During this period, the community was still very small, and internal communication was easy. Half a century later, in line with the overall population growth of Jakarta, the Torajan diaspora in and around the city has increased to about 1,80o households, or approximately 9,000 people. Three generations of Torajans already live in Jakarta. The first migrants nearly all consider themselves as Torajan, while some of their children and grandchildren have never been to Tana Toraja and feel more Indonesian than Torajan. However, this does not mean that they have completely broken with their relatives in Tana Toraja. Most travel to the highlands once in a while to attend a funeral ceremony. Unlike the migrants in Hilltop Village, the Torajans in Jakarta are spread all over the city and the neighbouring suburbs. Nowadays those Torajan migrants who live together in Greater Jakarta are either students at one of the many high schools or universities, or are working as government officials, soldiers, businessmen, nurses or doctors at one of the hospitals, or at private companies. Only a handful are skilled labourers or craftsmen. Most of them come from the Torajan upper class and are well-educated. This makes Jakarta the wealthiest and most prestigious of the Torajan diaspora. ${ }^{16}$

Torajans in Greater Jakarta are well organized into entities on three levels: kerukunan; church parishes; and an ikatan. Kerukunan are the most important, for they settle disputes, organize wedding ceremonies and

16 Apa dan Siapa (What and Who), a book written by Torajans for Torajans (Kurapak 2001), describes the fifty most prestigious Torajans in the world. Thirty of them are living in Jabotabek (Jakarta, Bogor, Tangerang, and Bekasi). While the criteria set for selecting these people might be debatable, the book at least gives some indication of where important members of the Torajan community are located. 
death rituals, and raise funds for people in need. They also have a social function by exchanging information about Tana Toraja and about job vacancies in Jakarta, and in bringing people together in a congenial atmosphere. Kerukunan are loosely structured, based on kinship, village or region of origin in Tana Toraja. There are fourteen active kerukunan in the Jakarta area, including one for Muslim Torajans. ${ }^{17}$ In addition to the kerukunan, Greater Jakarta has twelve church communities of which nine parishes are part of the Gereja Toraja (established by and for Protestant Torajans), one a Catholic church (Persekutan Umat Katolik Toraja) and two Pentecostal churches. The church as an institution, besides serving people's religious needs, provides Torajan migrants with a support network through funds for education, healthcare and support for the disabled and vulnerable. The church has also taken over some tasks that used to be performed by the kerukunan by binding people together at social activities such as sports, feasts and Sunday services. It functions as a major communication channel among the large number of people join congregations. Pa'Wanto, a Torajan migrant in Sejabotabek, said:

when a Torajan family newly arrives in Jakarta, or when someone is in the hospital, it will be announced in the church. For example, two years ago my son lay in the hospital in Makasssar with cancer. Because he was not getting better, he was transferred to the Cipto general hospital in Jakarta. My cousin went to church and told the minister about it. He then announced it to the church community. Thereupon, two of the wealthiest Torajans in Jakarta visited the hospital: one is the President Director of a shipping company, and the other is a lieutenant colonel in the army. Their wives and my wife were old schoolmates from Rantepao, and they wanted to do something for us. They gave us money for treatment and gave us mental support. Nevertheless, my son did not survive.

The third level on which Torajans are organized in Jakarta is the Ikatan Keluarga Toraja Jakarta (IKAT Jakarta). The association was founded by four notable Torajans in $195^{8}$ to strengthen and replace the KMT that had been established in the early 1950 (see discussion above). ${ }^{18}$ The IKAT is an officially registered association with a chairman, secretary and other

17 The following kerukunan can be found in and around Jakarta: Kerukunan Ikat Depok, Kerukunan Tallu Lembangna, Kerukunan Kesu', Kerukuan Buntao' Rantebua, Kerukunan Bassi Sang Tempe'(Bastem), Kerukunan Sa'dan Balusu, Kerukunan Sanda MamaseMamasa, Kerukuan Simbuang-Bua Kayu, Kerukunan Denpiku-Paris, Kerukunan Tikala, Kerukunan Saluputti, Kerukunan Muslim Toraya (KMT), Gereja Kibait and Persatuan Umat Katolik Toraja (PUKAT).

18 Currently, the word 'Jakarta' when used in combination with IKAT has been replaced by Sejabotabek, indicating Jakarta, Bogor, Tangerang and Bekasi. 
officers. It incorporates ten sub-IKATs that are spread over the various neighbourhoods and one IKAT for students, Ikatan Mahasiswa Toraja (IMT) Jakarta. As with other associations, IKAT Sejabotabek organizes social gatherings at Christmas and Easter. Further, they occasionally organize workshops or seminars when there is a specific issue or problem that involves the Torajan diaspora in the Jakarta area as a whole. These issues can vary from government plans to reorganize the administration in Tana Toraja, to potential attacks on Torajan churches by Muslim extremists in Jakarta on Christmas Eve. Although the main aim of IKAT is a religious one, it also provides some social support. A good example is the case of Toban Sampetoding whose father died in a Jakarta hospital. After the death, Toban, her stepmother and two sisters were in dire straits. The people from IKAT took over the organization and financing of transporting the corpse back to Tana Toraja for a decent funeral.

The Torajan diaspora in Greater Jakarta stands out for its efficient and effective organization. In Jakarta they live in a multicultural, metropolitan environment with people from different ethnic backgrounds and cultures: at work, in their neighbourhood, and also in their families. This contrasts with the people of Hilltop village in Malaysia who most of the time live among fellow Torajans. The Torajan migrant community in Jakarta also has a much longer history than the much younger migrant community in Hilltop village. However, the two diasporas also share some common characteristics. We can draw a comparison of the three similar lines or levels of organization: the kerukunan, the church, and the IKAT. The kerukunan functions in both communities as a mutual support system and also as a social framework to keep the migrant community together by organizing special meetings. The church as an organization serves people's religious needs, provides social security, cements people together through social events and provides a communication channel. The IKAT also has social binding and social security functions but differs from the other organizations due to its political function. The IKAT in Jakarta is particularly effcient and strong in triggering discussions about particular subjects that touch the migrant community in their locality (such as the Torajan identity within Jakarta), as well as in the heartland (such as the discussion about the large investments in funeral ceremonies). To summarize, both Torajan diasporas are made up of well-organized networks run along similar lines (kerukunan, church parishes and IKAT) that aim on the one hand to secure the social and financial wellbeing of their communities and, on the other, to maintain close contacts with those remaining in Tana Toraja. 
From this short overview, the picture might be emerging of a harmonious diasporic tradition among Torajans. However, in all the migrant communities there are Torajans who dissociate themselves from their fellow-migrants and some who even purposefully cut their ties with the homeland. Such cases are mainly people from the lowest classes-ones who have failed to succeed in their new environment, accumulated many debts to other Torajans that they are unable to repay, or have lost face in the highlands. However, this is not a common occurrence, and the characteristics discussed above as typical of the Jakarta area and Hilltop Village are shared by all the Torajan diasporas in Southeast Asia, and probably also by others around the world. The idea that 'different settings lead to the same outcome' is typical for the Torajan diaspora and cannot be generalized to all other ethnic associations in the cities of Indonesia. After investigating Toba Batak ethnic associations in the three Indonesian cities of Medan, Bandung and Jakarta, for example, Bruner (1972:227) concluded that 'the three cities provide very different social environments for their Toba Batak migrant communities, and this is reflected in the different ethnic structures that emerged'.

\section{Migrant Networks and Organizations}

The Protestant Torajan church is spread across Indonesia (and beyond) and is the 'umbrella' which shelters the majority of the migrant Protestant Torajans (about 75 per cent of Torajans are Protestants). The church is well organized and has its headquarters in Rantepao. Each parish has three groups that cater for specific categories of Torajans:a women's group (Persekutan Wanita Gereja Toraja, PWGT); a youth group (Persekutan Pemuda Gereja Toraja, PPGT); and a Sunday class (Sekolah Minggu Kebaktian Madia, SMKM). There are also various choirs that regularly meet to practice. In this way, the church plays a central part in the social life of many migrants. Some women will meet each other three times a week or more: Sunday at the service, Tuesday for choir rehearsal, and Thursday with the women's group. Catholic Torajans face a different setting as the Catholic Church is not organized along ethnic lines. In general they, therefore, share the church with Catholics from other ethnic groups, most notably from Flores, East Timor, Central Sumatra (Batak), the Moluccas, and the Chinese. Mathias, for example, is working for a mining company in Papua (Jayapura) and is representative of the Torajan Catholics over there. His church community includes people from a variety of ethnic backgrounds, and Torajans make up only a small minority. 
However, on religious holidays (particularly Christmas), Catholic and Protestant Torajans come together to celebrate within their kerukunan.

The idea of the kerukunan actually stems from the Protestant Torajan church, where this organizational model was introduced to prepare for collective Christmas celebrations. Nowadays, kerukunan can be found in almost every Torajan diaspora and its original function has broadened. The organization of kerukunan is relatively flexible and varies from very strict to loosely structured, and some are more active than others. In Kendari (Southeast Sulawesi), the Lemo Rarukan kerukunan (named after a village in Southern Tana Toraja) brings together all the 40 to $5^{\circ}$ households that originated from that particular village. This kerukunan is active in organizing wedding and funeral ceremonies in the same way as is done in Tana Toraja. This requires a lot of labour and funds. When a member of the kerukunan is involved in the organization of such a ceremony, the other members will automatically help in the form of labour, money and material: 'Maringana disingkai' sola uasang' or 'light and heavy work we do it together'. The group has its own chairs, plates and spoons ready for these events.

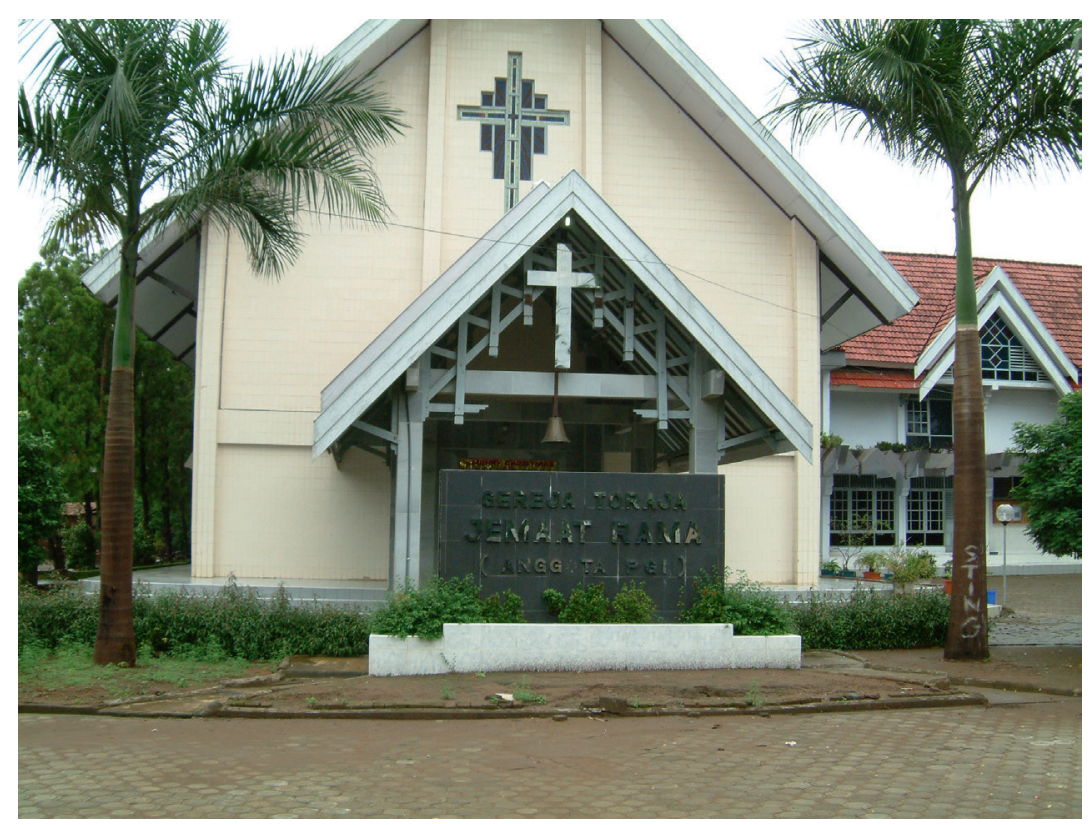

Ill. 3.1. Toraja church in Makassar (photo by Wim Jakobs). 
The Torajan diaspora in Makassar has the largest number of kerukunan. ${ }^{19} \mathrm{It}$ is estimated that there are between 80 and 100 Torajan kerukunan in Makassar, but that only 50 to 60 of these are active. Kerukunan membership is based on district, village, kinship, religion or university enrolment. Some of the larger (district) kerukunan are sub-divided into smaller kerukunan. As a consequence, the vast majority of Torajan migrants can be involved in more than one kerukunan. A Torajan migrant in Makassar explains:

I am a member of five kerukunan: one of my wife's father's family, a second of my wife's mother's family, another of my father's family, a fourth of my mother's family, and finally the one which is made up of people that originate from the village I grew up. The main purpose of a kerukunan in Makassar is to celebrate particular religious events together and to give money or a hand when a relative of one of the members dies. Each member has to contribute some money once in a while. When a relative in the village of origin dies, someone from that village comes to Makassar to collect money for the funeral expenses.

Another Torajan migrant told me that Torajans in Makassar are imbued with organizational life: 'For example, I am the chairman of the Torajan parish RAMA, a member of three kerukunan and several savings groups (arisan), a singer in the church choir and secretary of the Kombongan Sang Torayan. "kita bermasyarakat" (we form one group). We have to be involved into society to be able to live.'

In Makassar there are also various levels of Torajan organization. It is worth analysing the Kombongan Sang Torayan (KST), a group or organization of one Torajan community which can be loosely compared with IKAT in Jakarta. KST is an umbrella organization that includes all the kerukunan in Makassar and was established in the mid 1990s when there were several clashes in Makassar between Torajans and Bugis. The governor at that time requested the Torajan migrant community to set up an organization in which all the Makassar-based Torajan kerukunan were represented to enable negotiations between the two ethnic groups to take place. Since its establishment, the KST has organized several meetings around topics that concern the whole Torajan community in Makassar. In addition to playing a part in solving ethnic conflicts in Makassar, it became an intermediary between Torajans in Makassar and those in Tana Toraja. For example, after the Indonesian decentralization laws were launched in

19 Not all Torajan organizations in Makassar are literally called a kerukunan, but ikatan and keluarga (family) also have, in essence, the same function and objectives. 
2001, a large meeting was organized between those in favour and those against dividing the district of Tana Toraja. Along with the board of KST and 60 representatives from the kerukunan in Makassar, the meeting was attended by the head of the Tana Toraja district and his entourage. These kinds of meetings are held only once or twice a year, depending on the problems that arise for the Torajan diaspora. The KST thus does not have individual members but rather the kerukunan, or better their representatives, chaired by a rich Torajan businessman who also takes care of most expenses involved with the organization of these meetings. As Pa'Salusu explains, 'When a Torajan organization is set up, they look first to the people who are rich enough to pay for the organization of the meetings. In that sense I would call these kinds of organizations an elite system.'

In practice, the IKAT in Jakarta is considered to be much more effective in a social, political and economic sense than the KST in Makassar. Moreover, because of the rapid growth of Torajan diasporas, and the increasing tensions between Torajans and Muslim groups, an increasing number of diasporas nowadays establish their own IKATs in order to unite several kerukunan. The IKATs in the Province of Papua (IKAT Propinsi Papua) and in East Kalimantan especially are on the rise and extend their influence to other diasporas. Whereas most issues were formerly only discussed in either Makassar or Jakarta, or between the representatives of both diasporas, some other diasporas have now become powerful enough to demand a role in the protection of Torajan interests in the national arena and/or to claim a voice in discussions about any problems or policy regulations in Tana Toraja. Eventually, in December 2003, representatives from 30 Torajan diasporas within Indonesia (the chairmen of the IKATs) came together in one of the finest hotels in Tana Toraja to discuss the possible establishment of a single national Torajan association. Seven board members were elected during this meeting, but any further steps toward a national Torajan organization were not clearly taken at that time. ${ }^{20}$

Such translocal/national organizations linking many diasporas and often also the home community already exist at a lower level. For example, migrants who originate from the remote village of Baruppu, which is located at the northwestern tip of Tana Toraja, are organized in the Ikatan Sosial Keluarga Baruppu (ISKB). The ISKB consists of several ikatans that

20 Although not decided upon at that time, several names were suggested for the National Torajan organization: Kombongan Kalua, Masyarakat Toraja Sang Torayaan, Himpunan Keluarga Toraja Indonesia, Kerukunan Keluarga Toraja Nasional, and Ikatan Keluarga Toraja Indonesia (Kareba 2004). 
are located in the cities of Indonesia and Malaysia where considerable numbers of people from Baruppu are living. ISKB's central office is located in Makassar. Every five years, all the people from ISKB gather in the village of Baruppu to organize a thanksgiving ceremony. However, here we also find an elite bias; several people have complained that 'ISKB only functions well for the rich people and their relatives. If there are poor people in need the others in ISKB do not care.'

In addition to these kinds of translocal organizations in which money, goods and information are transferred across local and national borders, there are less-formalised interactions between Torajans from the different diasporas. Let us return briefly to the example of Pa'Wanto's son who died in Jakarta from cancer. While the transportation of the corpse from Jakarta to Makassar was arranged by IKAT Jabotabek, the Torajan society in Makassar took over the responsibilities as soon as the corpse arrived at the airport. The kerukunan of Tikala financially and emotionally assisted Pa'Wanto in organizing his son's funeral in Makassar. However, after the body was buried, relatives in Tana Toraja indicated that the body should be brought back to the home village for a decent funeral ceremony. After three months, the body finally arrived in Tana Toraja, again with the financial and physical support of the Makassar migrant community.

To summarize: the Torajan community is growing larger and becoming more widely spread. The increasing scale of the Torajan migrant world, and pressures from outside, have led to an all-embracing Torajan organization. Or as Lineton (1975) pointed out for the Bugis migrant society 'homeland and migrant societies form two sections of one social system'. IKAT types of organizations are rapidly emerging in various regions as a mechanism to connect lower-level organizations, such as the kerukunan and church parishes, to other migrant communities, and also to an all-embracing Torajan organization.

\section{(Trans)migrants in the City: The Case of Makassar}

Makassar is an important node in the Torajan world, a place where people maintain forward (to other migrant communities) as well as backward (with Tana Toraja) ties. To some extent the city has become an economic extension of Tana Toraja through providing a new field for work and income. Moreover, in Makassar the Torajan world is reproduced and reconstructed (for example through the wall painting at the back of the church discussed in the introduction of this study). New cultural models 
are developed of Tana Toraja that come close to what already exists in the homeland, but these models come out differently because Torajan migrants have to cope with the 'modern' urban world and context. Urban elites believe they know better what Tana Toraja needs than the elders and politicians in Tana Toraja itself. When Tana Toraja is recreated in Makassar, the question arises as to how this occurs?

Torajan migrants are of course not living in a social vacuum. The image of Makassar among most Indonesians is that of a 'hot city'; referring both to the climate and to the people inhabiting the city. The two major ethnic groups in the city are from South Sulawesi itself: the Bugis and Makasar. ${ }^{21}$ 'Both have a reputation of being short-fused and obsessed with prestige and with honour and shame (siri'); other Indonesians see them as "hot" (panas) and "emotional" (banyak emosi), and the area is perceived as a "hot region" (daerah panas)' (Antweiler 1995:3). The Bugis and Makasar share many cultural features and are both adherents to Islam. Torajans, on the other hand, are seen as socially inferior by the Bugis and Makasar and are predominantly Christian. In the following, I will elaborate on the way Torajans make a living in this apparently 'hot' city and the way this affects the world of those remaining in the homeland of Tana Toraja.

\section{Makassar: Microcosm of the Eastern Seas ${ }^{22}$}

Makassar has the appearance of a typical Indonesian city; in the centre we find its government offices, Chinese and Indonesian shops and markets, Muslim and Christian places of worship, a mixture of well-to-do and poor neighbourhoods, and a public life conducted in Bahasa Indonesia. ${ }^{23}$

21 I use 'Makasar' to refer to the ethnic group that is predominantly located along the southern coast of South Sulawesi. The term with one 's' is commonly so used in the literature and helps to avoid confusion with the city 'Makassar', which is written with two s's.

22 This title is partly derived from Antweiler (2001).

23 From the beginning of the seventeenth century, Makassar has been a strategic location in Southeast Asia's trading system. At that time, it started to discover its 'commercial vocation as a base for all those seeking to evade the VOC's attempts to monopolize the Moluccan spice trade' (Reid 2000:57). The Portuguese made it their principal Southeast Asian base after the fall of Malacca in 1511 . Soon, the city of Makassar became an important base for staple trade, supplying spices to European, Indian and Chinese buyers as well as a typical 'Southeast Asian entrepôt' where popular trading goods, such as porcelain, Mexican silver and Indian cloth, were exchanged Merchants from England, Denmark, Portugal, India and China established warehouses and started to live in the area. According to Reid (2000:58), the city grew quickly from a population of only a few thousand in the 1590 s to about 100,000 at its peak in 1640-1660. 'This would have made it one of the six biggest cities in Southeast Asia, and as big as many European capitals'With a population of about 1.4 million today, Makassar remains the largest city in the eastern part of Indonesia, and it is estimated that it will further grow to 2.2 million by the year 2015 (Forbes 1981; JICA 1996). 
The town is located next to the sea and has a harbour where impressively stylish wooden Bugis sailing boats lie against a background of large cargo ships. The recently developed harbour facilities, together with a domestic and international airport, help fulfill the modern role of the city as the gateway to Eastern Indonesia and the trigger for economic growth of the region. The rapid economic growth that occurred in Indonesia before the crisis in the 1990s largely excluded the Eastern Indonesian provinces. As Turner (2003:93) noted, "The regional disparities perpetuated by this polarization have meant that not only is the local economy of Makassar a peripheral one, but also that the local political sphere has been controlled largely by those outside of the island. Not surprisingly, local development has been slow, with a high incidence of poverty and un/underemployment remaining.' Because Makassar was largely bypassed by industrialization, the city had been 'sheltered from many of the direct impacts of the economic crisis that [in the late 1990s] hit Java's modern economic sectors, such as construction, manufacturing, and financial services' (Turner 2000:346). Forrester (1999) concluded that there had not been such high unemployment rates as in Java where they had been a consequence of closing factories and retailers.

Despite, Makassar's status as a 'peripheral economic zone, vis-à-vis the western major islands of Java and Sumatra', the city is nevertheless the most important economic centre in Eastern Indonesia. Moreover, it is a transportation node and critical in providing higher education opportunities for the Eastern Indonesian peoples, such as those from Flores, Timor and the Moluccas (Antweiler 2001). After the national government's decision in the late 199os to nominate Makassar as one of Indonesia's centres of 'special development,', ${ }^{24}$ the building sector and economy have flourished.

With people drawn to Makassar to work, pursue education, or set up a business, the city has become a mixture of various ethnic groups, a microcosm of the eastern seas. However, as Antweiler (2001) noted, 'Makassar is not simply a "city of minorities" like for example Medan in Sumatra' but is dominated by the four main ethnic groups of South Sulawesi itself: Bugis, Makasar, Mandar and Torajans. The largest group, the Bugis (52 per cent), ${ }^{25}$

24 The others being Jakarta, Surabaya, Medan and Ambon (Antweiler 2001).

25 This figure is an estimate by Abustam (1988:19). More recent information about the ethnic composition of Makassar's population is not available. However, in an interview with Turner (2003: 84) an official at PUKTI (Centre for the Development of Small Businesses in the Eastern Indonesian Region) 'estimated that in 1997, 30 per cent of the population 
are known as seafarers and have a 'reputation of being aggressively competitive, perhaps due to the struggle for political hegemony, rivalry for social status and to avoid siri', commonly a loss of honour and dignity, but historically more complex, embodying social solidarity, social identity, prestige and self respect'(Mattulada 1982 in Morrel 1998:161). Although closely related, the Makasar (25 per cent) are often seen as culturally inferior by the Bugis due to their image as poor farmers who have migrated to the city and are willing to undertake low status jobs (Antweiler 1994). Other major groups in Makassar include the Mandar people (13 per cent, also from South Sulawesi) who are culturally linked to the Bugis people, and the Torajan people who make up about 10 per cent of the total population in Makassar. The last group are considered to be of lower descent than the Bugis and Makasar, and are generally referred to as a source of slaves in the past.

Still today, the ethnic categories remain important and there are sharp boundaries between them. Just as Antweiler (1995:4) observed during his fieldwork in a neighbourhood of Makassar, I found that '[p] eople quickly and unambiguously refer to themselves and others as Bugis, Makassar, Mandar, or Toraja (the main south Sulawesi groups) and other ones, as for example Orang Jawa (Javanese), Orang Timor and Orang Cina (Chinese Indonesians; officially Tionghoa).' Consequently, racial violence is not uncommon, especially between the ethnic groups of the Muslim lowlands and the Christians from the highlands of Tana Toraja. Nevertheless, members of the many different ethnic groups often interact within economic or working relationships through inter-ethnic marriages and/or through residing in the same neighbourhoods. Antweiler (2001) argues that '[d] espite some remaining ethnic names of urban quarters [such as kampung RAMA], many areas are almost unsegregated in ethnic terms today'.

\section{Arriving in the City and Finding Shelter}

The wider region of the Makassar municipality (kotamadya) comprises $172 \mathrm{~km}^{2}$. The inner city is the oldest part, located near the sea and having the highest population density. From here, the city stretches about 20 kilometres inland to the east, where the population density is one fourth lower than in the centre. This is also where the housing estates for the well-to-do

were Bugis, 40 per cent were Makassar, with the remainder consisting of Mandar (5 per cent), Toraja ( 5 per cent), Chinese ( 3 per cent), and 17 per cent "others", among whom were Javanese and those from the Outer Islands.' Except for the total numbers of Bugis and Makasar, these estimations are close to my own impression. 
are to be found. Most 'slum' areas are on the fringes of the central part near the sea (JICA 1996). Torajans are scattered all over the city, from the wards of the well-to-do citizens to the slum areas, reflecting their individual social status (Nooy-Palm et al. 1979b:32). There are somewhat higher concentrations of Torajan households in certain areas (see Map 3.3). The older neighbourhoods, those that developed in the 1930s and 1950s, are close to the sea, in the centre of the city (around Jalan Bawakaraeng and kampung Dadi) and in the southern part (around Jalan Cendrawasih and in Tamalate). The other quarters are newer and generally to the east of the centre (Kampung Rama) and further east (Tamalanrea). Kampung RAMA is the only quarter in Makassar that houses virtually only completely Torajan people. It was established in the 196os by Torajans from Rantepao and Makale (the only two towns in Tana Toraja) and today there are about 400 Torajan households. ${ }^{26}$

As we have observed earlier, Torajans tend not to move to Makassar on their own but through their networks of relatives and friends who originate from the same village or region in the highlands. Upon arrival, these people often provide initial shelter, food, information about the city's 'do's and don'ts', and the networks that help to create the conditions for settling in the city, such as finding employment and shelter. This does not mean that new arrivals automatically leave the welcoming house as soon as they find employment and alternative shelter. Most Torajans have relatives from the highlands staying in their houses, or 'living-ins' as Nooy-Palm (1979b) calls them. I seldom came across Torajan households in Makassar that consisted solely of a nuclear family (parents and their children).

Students and poor, or unemployed, relatives are generally not expected to pay for their expenses but "take on the functions of "helpers" in their urban relatives' homes in exchange for housing and assistance with tuition' (Adams 2000:171). Rintik, for example, who is a policeman from Rembon living in a boarding house provided by the police department (Asrama polisi) in the eastern part of Makassar helps out his relatives.

Together with his wife, who is a nurse in a Catholic hospital, they are taking care of seven relatives from the highlands plus their own two children. Thus, the tiny, one-floor, official residence with two bedrooms plus a living room and annex kitchen, provides shelter for 11 people. None of these relatives have an income. A 26-year-old niece stopped working in order to take care of her child after her husband died and the other 'living-ins' are still at school.

26 In 1992, kampung RAMA consisted of 406 households of which 382 originated from Tana Toraja, 11 from Pare Pare and 13 from elsewhere in Makassar (Hafid 1996-1997:37). 


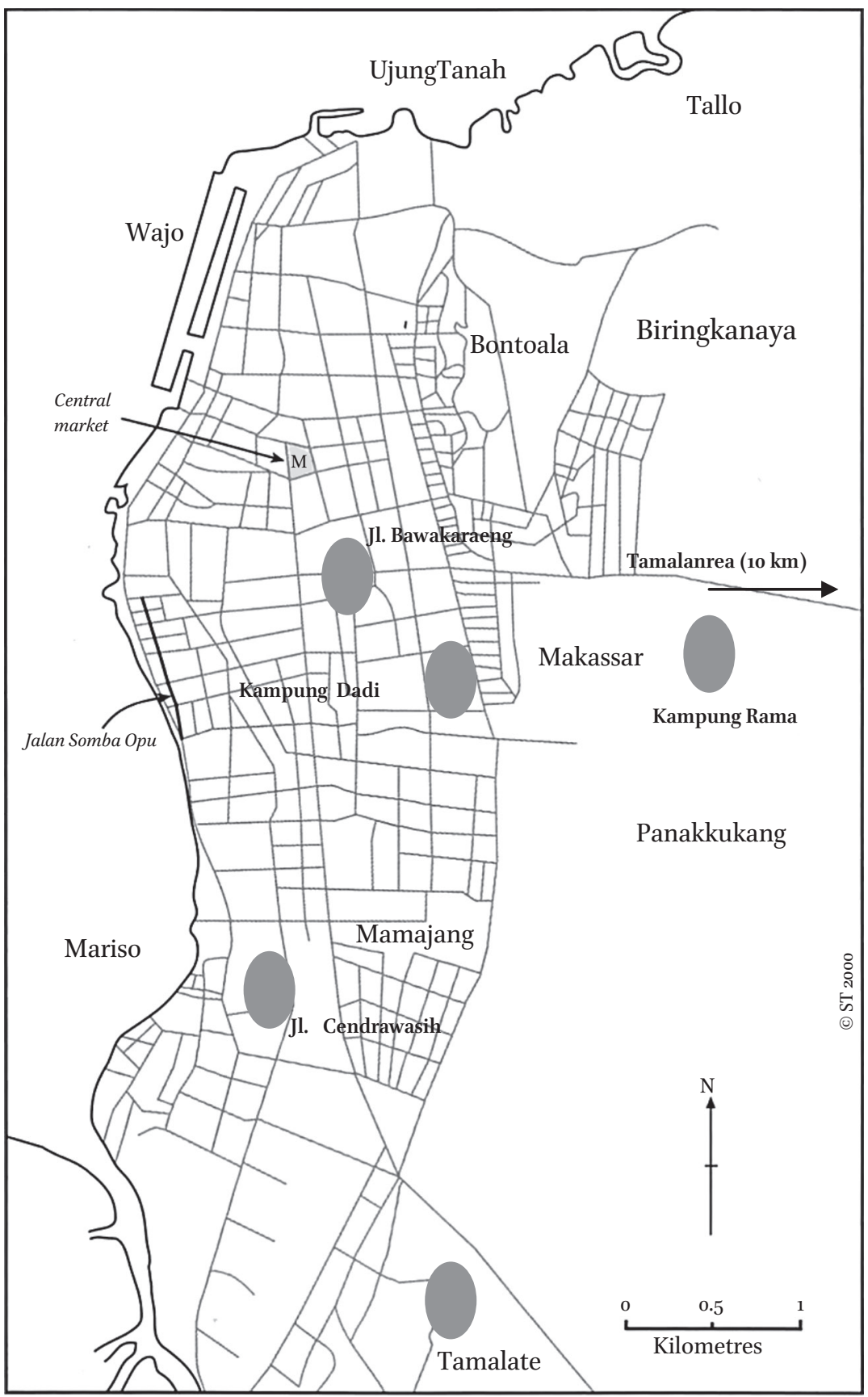

Map 3.3. Concentrations of Torajan households in Makassar.

Source: Map based on city layout from Forbes (1979:5). 
Rintik and his wife are paying all the expenses while the youngsters take care of the shopping and food preparation. One year earlier, Rintik was even accommodating 20 relatives in his house, but some have since found employment and moved out, while others have returned to Tana Toraja.

In addition to visiting relatives, the well-to-do also have Torajan servants or gardeners living in their houses. These are provided with food, a place to stay and a small amount of money in return for their services. Usually, these servants come from lower class families from the same region or village in the highlands. In rare cases, people from the highest social class (puang) even bring their former slaves to their urban homes. The puang take care of all the expenses of the slaves and pay some 'pocket money'. Occasionally relatives of a house-owner will take care of a house while the owner (and his immediate family) are no longer living there. Makassar is often a stepping-stone for migration to other places in the archipelago. Houseowners, often retain their property in Makassar as a base to which they can always return in case of adversities elsewhere but also because it is conveniently located on the way to Tana Toraja. It is not uncommon for the people living in these 'abandoned' houses to have their own 'living-ins'.

Next to these purely Torajan constellations of households, I came across several mixed-ethnic households. My own estimation is that about five to ten percent of Torajans in Makassar live in mixed-ethnic households. Some of these households are a result of inter-ethnic marriages, where the spouses often had Christian backgrounds and originated from Flores, Timor or north Sumatra (Batak). Some Torajans had also married a Muslim with a Bugis or Makasar ethnic background. Others, usually unmarried Torajans, live in affluent middle-class Chinese or Bugis households. Such Torajans, often low-ranking, work in these households as servants or as labourers in an attached business. Rosmina, for instance, stays with her cousin in a small room above a Chinese grocer's shop.

Together with her cousin, a Makasar girl, and the Chinese owner and his wife, they make up one household. Next to shelter, the Chinese shop owners provide food and a small salary ( $\mathrm{Rp} 300,000$ per month). Because Rosmina is working seven days a week from 6.30 am to $9.30 \mathrm{pm}$, she relies almost completely on the other household members, to whom she has to talk to in the Indonesian language. However, to her Torajan colleagues or customers, she will immediately switch to the Torajan language.

Torajans who came to the provincial capital some time ago (between the 1930s and the 1970s) generally own a house. Often these people have been or are still working as policemen, soldiers, teachers, or civil servants at one 
of the many government offices in Makassar. Other Torajans have to pay rent, in either money or labour, or depend on the good will of family members to provide accommodation.

\section{Living and Working in Makassar}

The neighbourhood in which Torajans live is a reflection of their status. Status, in turn, is often derived to a great extent from someone's occupation. Because Makassar is a widespread city and congested by traffic, most people prefer to live close to their work. Consequently, besides the time period of migrant arrivals, many neighbourhoods represent particular jobs or orientations. The area of Tamalanrea (see map 3.3), for example, is close to Universitas Hasanuddin (UNHAS), one of the largest and oldest universities in eastern Indonesia. The area also houses a Christian University (UKIP) and various high schools, and most Torajans living in this area are either teaching or studying at one of these institutions. Just as at UKIP, nearly all the students at the Catholic University of Adma Jaya and the Christian School of Theology (STT), which are located in the southern part of Makassar, come from Tana Toraja. Some of these students live in boarding houses in the vicinity of these schools and universities. Others live with their relatives in and around Jalan Cendrawasih, another neighbourhood with a high concentration of Torajans. Kampung Dadi is a less sophisticated area of town that also houses a large number of Torajans. Torajans with a high income do not live in this neighbourhood, but it still provides a more pleasant impression than other Torajan wards in the town where the houses are so close together that their roofs touch each other. Although the streets have become a little busier nowadays, the Dadi neighbourhood still fits the description by Nooy-Palm (1979b) about three decades earlier: 'In Dadi there is much space between the houses, providing room for the children to play their games, whilst adults have built their badminton fields.' Today, most people living in kampung Dadi are employed by the government (including the army, police, primary and secondary schools and those with white collar jobs) and several others are working as carpenters or as servants in one of the hotels in Makassar.

A large number of the Torajans in Makassar have a government position and live in the vicinity of their departments or even in special compounds where houses are provided by the government (especially for the police and army). Others are studying and living in or near their schools and universities. Even more are working in stores, as servants in Chinese, Bugis or Torajan households, in the hotel and catering industry, or as manual 
labourers. Others are employed in the shoe, furniture and rattan industries. Most of these people are living in the more modest or shanty-type of neighbourhoods 'where the roofs of the houses touch each other'. This is, for example, true of Lia, who is living with seven other people in a tiny shack in a slum area in the northern part of Makassar.

The partly two-storey wooden shack is completely jammed in between other houses. Lia is paying Rp 600,000 per year in rent for the small plot of land on which the house is built. The house had already been built by her uncle when Lia arrived in 1990. Since then, she has patched it up as best as she can. The house has a small room of three by three metre which is used both as a place to live and one to sleep in. At the back is a kitchen/bath room and toilet and, on the upper floor, another small bedroom. The roof on top of the front room is made of zink which heats up when the sun shines and leaks when it rains. Lia works in a bar, dancing, earning Rp 300,00o per month. She shares the house with her sister Selfi, her first cousins Anni and Eli, and Eli's husband from Flores and their two children. Selfi is working at a shoe store, Anni is working part-time as a nurse at a Catholic hospital, Eli is unemployed and her husband is a waiter at a hotel on the city's boulevard. They all pool their incomes to make ends meet. The situation of the other people in the neighbourhood is not so very different. Like Lia, most neighbours come from the Southern part of Tana Toraja, and are from the lowest social rank, some are even slaves. They are working in shops, making furniture and handicrafts, or selling bakso (soup with meatballs).

Lia's situation stands in sharp contrast to that of the Torajan businessman Brent Litha, owner of a bus company (with the same name) that has buses running throughout South Sulawesi. He also owns a coffee company that exports coffee from Tana Toraja to markets all over the world. Brent lives with his family along a busy road near the centre of town. Before reaching his house one has to pass a large electronically operated gate. His twostorey house has all the luxuries one can think of. This businessman represents the Torajan ideal. Although there are very few financially successful Torajan businessmen in Makassar, together they own part of the city's major taxi company, some large hotels, companies and shops. In general, Torajans are not well-known for their business attitudes, and the few businesses set up by Torajans tend to remain rather small in size. According to Turner (2005:266), there is some notable occupational demarcation along ethnic lines in the production of small-scale enterprise goods in Makassar city. As Turner observes, Torajans continue to dominate the shoe business as they did in the early days (see also Abustam 1975), while other businesses are difficult to enter. Given this situation, networks appear to be pivotal in finding employment. Some people in a Torajan village 
complained to me that its inhabitants could not find any work in Makassar simply because there are hardly any other villagers or relatives living in the city. In other words, finding a job in Makassar almost completely depends on 'who you know and not what you know', as Woolcock (1998) phrased it.

\section{Social Relations and Networks}

As described above, migration to the city and job searching is generally facilitated by a family member or a fellow villager already in the city, but how do Torajans build up their social relationships and networks afterwards? When it all comes down to 'who you know' in finding a job, shelter or information about forthcoming ceremonies or events, who are these 'who's' and how and where do 'new arrivals' meet them. In other words, what are the typical places and organizations where Torajan city dwellers meet other Torajans, and what sort of people are most likely to be embedded in which Torajan networks?

As we saw earlier, the living situation of Torajans differs widely in the various city neighbourhoods. Some live almost completely among other Torajans, while others live in a neighbourhood dominated by people from other ethnic groups, and a few live in mixed-ethnic households. These different living situations lead to various constellations of social relations and networks in which Torajans become involved. Let me start by introducing the story of Kristina, a 28-year-old woman, who migrated to Makassar in 1994 after she finished high school (SMA) in Tana Toraja.

In 1994, Kristina came to the city in search of a job and stayed with her aunt, who was still single, in a small house in the southern part of Makassar. After one year, she found employment in a copy shop which was owned by a Chinese. She heard about the job vacancy from the Catholic priest of her church community, of which the Chinese owner was also a member. After two years working at the copy shop, Kristina became an employee at the Catholic university Adma Jaya. This time, she came to know about the job through her uncle who is also working at the administration office of the university. When Kristina left her job at the copy shop, her sister Marianne filled in her position. When Marianne left to go to Surabaya to find better paid employment, the job was again taken over by another sister, Herlina. Herlina dit not get along well with the Chinese owner and quit in 2004, along with a Bugis colleague and friend. At that time, she was finding it hard to find a new job. According to Herlina, there is no possibility of finding a job through the kerukunan because there are not many Torajans owning a company. 
Kristina now rents a small house not far from the university where she works. She moved to the house in 1996 and shared with her cousin who was already living there. After one year, her cousin moved to Papua, and Kristina's sister Herlina moved in. Kristina is married to a man from Tana Toraja who was searching for employment in Irian Jaya at that time. Together, they have since had a young daughter, Thersa, who is living with Kristina's parents in Tana Toraja. In line with Torajan customs, Kristina gave birth to her child in her parents' house in Tana Toraja. Not uncommonly either, her parents are now taking care of the child because Kristina needs to work and her husband is in Irian Jaya. One week before I visited Kristina, her parents came to Makassar with Thersa to celebrate her first birthday. The party was also attended by a couple of Torajan family members. Besides the ones mentioned above, another daughter, Selviana, came along with her aunt and uncle. Selviana is studying at a secondary school (SMA) in Makassar and lives with her aunt, who works with Kristina at the Catholic university. This aunt is still single and childless and financially supports Selviana's education. They share the house with a disabled uncle of Kristina, who is unable to work. Fitriansa, a cousin of Kristina who lives on the other side of town in a police compound, also attended the birthday party together with his sister. All these family members come from the same village, Palipu', in the southern part of Tana Toraja. These family members are the ones closest to Kristina, and most of her social life is centred around these relations. Often her uncle and colleague visits Kristina and Herlina for a chat and to keep an eye on things. Kristina, frequently visits the other family members on a Sunday afternoon after the Catholic Mass has finished.

Besides her family, she sometimes sees other people from her home village at meetings organized by the Kerukunan Keluarga Besar Kandora (KKBK). KKBK was founded in 1975 as an organization for the people from three villages in Tana Toraja, including Palipu'. According to the chairman of KKBK, the main purpose of this organization is to strengthen the relationships among the people of Kandora and to support its members in times of need. 'If someone from Kandora is sick or dead, the sick person or the family of the deceased receive a certain amount of money to support them. Moreover, the members will physically and financially help with the organization of particular wedding or funeral ceremonies.' The KKBK annually arranges for a large Christmas celebration for all 100 households who are members of the organization. It also has a financial self-help organization, or arisan, that meets every month. Arisans are not only popular among Torajans but among people from all ethnic groups and layers of Indonesian society. The arisan within kerukunan Kandora has about 40 or 50 members who each contribute $\mathrm{Rp} 20,000$ per month to the monthly prize or jackpot. Because most meetings are held on the other side of town, Kristina only attends the large Christmas celebration. In spite of its social function, where lots of information is exchanged, the kerukunan has not proved very useful to Kristina's sister Herlina in finding work. 
Instead of travelling across town to participate in the KKBK arisan, Kristina is a member of an arisan at her workplace, which has 20 to $30 \mathrm{mem}$ bers. The members are mostly Torajans who also each pool $\mathrm{Rp} \mathrm{20,000} \mathrm{each}$ month. According to Kristina, 'this arisan is very helpful in making a living because once in a while you obtain a large amount of money, without the need to return it or pay any interest.'

The house which Kristina rents is located in a typical heterogeneous neighbourhood with Bugis, Javanese, Ambonese, Makasar, and many Torajans. When she returns home from her work, she usually sits outside to chat with her Makasar and Ambonese neighbours. However, besides this gossiping, as she calls it, she does not have much other interaction with her neighbours.

The situation of Kristina represents a typical Torajan network in Makassar; most of those involved are from the same region of origin, and often from the same village and/or shared ancestors. Apart from some relationships with people at work and in the neighbourhood, most interactions of importance occur within this network. Kerukunan are usually no more than an extension of these networks and do not directly include people from other regions in Tana Toraja or from other ethnic groups. Religion, on the other hand, or rather its performance, has proved to be a more useful means of establishing new relations outside existing networks. Especially in the Catholic church, where parishes include people from Timor and Flores, and some Chinese, Torajans are more likely to meet people from other ethnic backgrounds. Kristina found employment with the help of her church relationships, at a Chinese-owned copy shop. Often these interactions lead to inter-ethnic marriages. In fact, most of the interethnic marriages in Makassar I came across during my research involved Catholics. Such marriages will often have an impact on the kinds of networks in which the Torajans will participate. This also applies to Maria, who married a man from Flores, who was also a Catholic.

Maria, a woman in her 4os, came to Makassar ten years ago, following her husband who had found a job as a driver for the Universal Bank. She had met her husband, Hendrikus, in Maros, a city just one hour's drive north of Makassar. Before they married, Maria took care of her sister's household in Maros for over nine years. At the time I interviewed Maria, she was living in the rear part of a house together with her husband, two small children, her brother and her husband's nephew from Flores. For over three years, Hendrikus has now been working as a driver for an Australian oil company, which is run by a Chinese man from Java. He is the only person in the household earning an income ( $\mathrm{Rp} 600,000$ a month). The others are still studying in high school or primary school, while Maria is working as a housewife and taking care of her youngest daughter. 
Their two-storey dwelling is located in the eastern part of the city in a neighbourhood which is predominantly inhabited by Makasar, but also houses some Bugis, Ambonese, Flores and three Torajan households. The neighbourhood appears quite sad and Maria's dwelling is rather small. Living with so many people on one salary, sometimes makes it hard to make ends meet. Although they get along well with their neighbours, it is difficult to borrow money from them during hard times because they charge over 20 per cent interest. At Hendrikus' workplace it is even harder to ask for help because, as he explains, he has only been working there for three years and has not managed to establish close relations with his colleagues. They have not joined any arisan, and the Catholic Kerukunan Flores (KKF) to whom they belong only consists of the Flores and Torajan households in the neighbourhood. The main purpose of this kerukunan is the organization of a Christmas celebration rather than the financial support of people in need.

Just like Kristina, Maria also comes from the village of Palipu'. However, as she tells, she rarely meets Torajans from her home area, apart from her sister in Maros. She does not even know the address of her cousin, the policeman who went to the birthday party of Kristina's daughter. Nor is she going to the kerukunan Kandora (KKBK). According to her, its members live all over town which will make it difficult to join any meetings. The Catholic church which Maria attends is quite far from her home, but she takes part in a Catholic praying group in the neighbourhood which meets regularly. Her relations with people in Makassar, outside the household, are rather weak. Her sister, on the other hand, has better connections in Maros and explains that, in the event of problems, she often turns to people from the same home area (including Torajans from the neighbouring district of Mamasa). The importance for Torajans of coming from the same region or area is often mentioned by them using the term 'solana', which literally means 'together'.

The isolation of Maria from other Torajans is neither related to her marriage with someone from another ethnic group, nor to her social background, as was the case with Lia (see former section). Lia came from a slave family, and the only way to escape from this position is to avoid all relations with Torajans in Makassar that come from the same region. This is a rather radical step, and I did not find many Torajans who took it on purpose. The reason for Maria being more-or-less isolated from other Torajans is, in my opinion, somewhat more differentiated. I see it as a combination of financial status, religion and place, along with her inter-ethnic marriage.

Let me start by explaining why financial status can influence a person's participation in Torajan networks. As I explained above, maintaining relations with Torajans takes money, effort, and time. Crisscrossing Makassar to visit other Torajans or joining a kerukunan consumes both time and money. Once in a while, Torajans have to contribute money to relatives, 
friends and acquaintances for forthcoming ceremonies in Makassar or in Tana Toraja. In fact, the main purposes of a kerukunan in Makassar are to celebrate particular religious events and to give money when a relative of one of its members dies, or for a forthcoming wedding. Each member therefore has to contribute some money on occasion, and this makes it impossible for some people to join one let alone several kerukunan. The richer people are, the more social relations they can afford, and the more they are involved in Torajan social organizations, often holding leadership positions.

Religion can be another way to cement particular Torajan networks (or to exclude people from them). Makassar has eleven Protestant Torajan churches (Gereja Toraja) in those neighbourhoods with the highest concentrations of Torajans. Each parish has several groups that cater for specific categories of Torajans and various choirs. Through this structure, people meet each other a couple of times a week, and the institution, so to speak, cements the social relations among its members who are predominantly Torajans. In contrast, the Catholic congregations in Makassar are a mix of ethnic groups, and the church rather discourages any direct relation between ethnicity and the church. Thus, instead of encouraging the realization of a large Torajan community or network, it impedes this process by suggesting that this is not necessarily essential. Consequently, the Protestant Torajans I met in Makassar tend to be more closely involved in Torajan networks and organizations than their Catholic equivalents.

Finally, place appears to be another variable that encourages or keeps people from involving themselves in relationships with other Torajans. When the density of Torajan households in a neighbourhood is high, it is more likely that most interactions in the life of these Torajans are undertaken with co-ethnics. This becomes apparent in the story of Lina, who is living in a street just outside kampung RAMA, densely populated with Torajans.

Lina heads the Makassar department for a Torajan lending and saving cooperative (KSP Balo' Toraja). In the small office at the back of her house she receives her Torajan clients in the mornings. In the afternoons, the 34-year-old woman is usually out visiting Torajan friends or relatives who live nearby for a little chat and some tea. Twice a week she spends the evening with her church choir to practice some hymns for the forthcoming service. On Sundays she goes to the service at the Gereja Toraja in Kampung RAMA, after which she joins some other church members at their homes for some drinks and food. Once in a while, she leaves the neighbourhood to do some shopping in one of the malls in the centre of the city, the only occasions when she meets non-Torajan people. 
The life of Lina contrasts strongly with Maria's social life, since she has hardly any Torajans living in the close vicinity. One can conclude that integration into networks and Torajan organizations is more-or-less shaped by the combination of the social and financial status of the migrant, his or her religion and marriage, and the place of the migrant's home. Interestingly, although work seemed to play a part in the way Torajans are integrated into networks and Torajan organizations, in most cases it only played a minor role.

The Torajan social space or field in Makassar thus consists of various localized Torajan networks that are based upon the neighbourhood, family, work, church, arisan or kerukunan. To some extent, these networks are a reflection or extension of the social structure in the homeland. These networks are 'bonded' and 'bridged', to use Woolcock's terminology (1998), by so-called key players or the urban Torajan elites. Such people usually head these groups and meet each other at various events such as weddings, Christmas celebrations, New Year receptions and more importantly, at ceremonial activities in Tana Toraja. On these occasions, new social relationships are formed and old ties are strengthened. To keep one's relationships strong, it is essential to participate in various such social happenings. Often ceremonies in Tana Toraja provide the best opportunities for people to invest in new and old social capital, because there they have much more time than in Makassar, where they are busy with their work. Given this tight system of social networks, members of the urban Torajan elite, such as Brent Litha and Pa'Salusu, are able to quickly mobilize many Torajans to raise money for funeral ceremonies or Christmas celebrations, in times of elections in Tana Toraja, or when conflicts emerge between Torajans and the Bugis in the city. As such, the Makassar elites exercize great influence over other local Torajans and also over the home region. When local elections are due, Torajan politicians go to Makassar to lobby for support from the Torajan elites over there, and by that they gain the loyalty of associates in Tana Toraja. If they have substantial objection, powerful migrants might even be able to prevent the implementation of particular policy measures in Tana Toraja. Therefore, the district head and his entourage regularly visit Makassar to find support for their plans from among the urban Torajan elites. In return, on their visits to Tana Toraja, these well-educated elites often provide unsolicited advice to the district head on issues such as education, healthcare, employment, tourism and, to a lesser extent, agriculture. These elites owe their important positions not only to their achievements in the city, but also to their financial contributions to funeral and house-inauguration ceremonies in Tana Toraja. 
Moving forward in Makassar cannot be achieved without social and financial contributions to the heartland of Tana Toraja.

\section{Communication between the Urban Migrants and the Homeland}

From the above it is clear that many Torajan migrants still return regularly to the highlands to participate in funerals, house-building ceremonies and/or weddings. The frequency of such trips depends on the distance between the place of migration and their homeland, the period of migration, the financial capital and employment of the migrant, and the importance of the forthcoming ceremony. However, even if Torajan migrants seldom return home, the vast majority still maintain close relations with the home community. The continuing significance of kinship in the lives of migrants long after they are settled in Makassar, and the growth over time in the type and quantity of transactions which take place between kin located in the two locations deserves further explanation (Basch et al. 1994:165). One cannot automatically assume that the Torajan migrant community in Makassar continues to have many relatives back home to whom it feels obligations. The impetus for keeping close ties with kin in the highlands is highly complex and requires an understanding of Torajan social organization and culture, which will be provided in Chapter 4 and 5 . In this section, I simply picture the channels through which information, goods and money are transferred.

The quantity of money and goods sent home to Tana Toraja on a daily basis becomes immediately clear when you enter the office of Litha, which has several buses running to Tana Toraja every day. A large stack of boxes is waiting to be transported to Tana Toraja on the night buses. A price list is hanging on the wall, detailing, the charges for carrying the various sizes of boxes, amounts of money, and letters to Makale or Rantepao. ${ }^{27}$ According to Delfi, this system functions very well.

In addition to money, she sends monthly a box with goods (salt, sugar, sweets, toiletries, etc.) home to her daughter Ritta in Tana Toraja. Ritta is 17 years old and rents a small apartment in the town of Rantepao where she is studying in high school. Delfi works in a café in Makassar and takes care of all Ritta's expenses. When Ritta picks up the box at the Litha office in Rantepao, she usually heads directly to the village of Palipu' where she was brought up by her grandparents (Delfi's parents). Most of the received goods

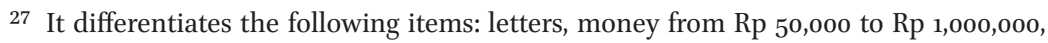
small boxes of Indomie (a popular brand of noodles) boxes with salt, computers, monitors, middle-sized boxes, and large boxes. 
will be distributed among them and a brother and sister of Delfi. Often, they also receive a little pocket money from Delfi.

Lucie uses another bus company and is also quite positive about this system. She often uses the company to send letters home to her village of Kondo'. The boyfriend of her cousin, who is living in Rantepao, usually picks up the letters at the local bus office and delivers them to Lucie's parents in the village. Mail headed in the other direction operates in the same way.

Money and goods are of course not only sent home from Makassar with the bus companies; these can also be carried by family, friends or acquaintances visiting the village or taken personally by the migrants themselves on a visit home. Another, but less used and less trusted, way involves transfers through the postal service or a bank, although not everyone is allowed to, or able to, open a bank account. Finally, some money is transferred through the Torajan lending and saving cooperation (KSP Balo' Toraja) which has an office in Makassar and several in Tana Toraja. According to the person heading the local office in Makassar, this channel is used very irregularly by Torajans and really only when migrants have to contribute large sums of money for forthcoming ceremonies. In practice, it is more regularly used for transferring money from parents in Tana Toraja to their children in Makassar. Forty students receive a combined Rp 20 million every month. It is not uncommon for parents in Tana Toraja to support their children during study in Makassar, but most students also receive support from their wealthier kin in the city. More customary are gifts of rice, coffee and the Torajan cookies traditionally served at ceremonies. Often I came across migrants who had brought some rice back from their visits to the highlands, or obtained some from returning relatives, friends or neighbours. Thus this transfer is not only a flow of goods and money in one direction, but it is also not a balanced exchange. Although the amount of money and goods transferred is hard to measure, virtually all migrants are sending something home. Beyond making a living in Makassar, most migrants are trying to save money for their kin in Tana Toraja or for forthcoming ceremonies.

In the past, information was usually passed from migrants to kin at home by letters, telegrams or through other Torajans who travelled back and forth. As a consequence, it could take several months before news about unexpected events in the home village reached migrants. Since then, through faster means of transportation and communication, the transfer of information has become much easier. The first advance was the 
introduction of an analogtelephone system in Tana Toraja in 1987 that provided telephone connections for some people, primarily for civil officers and the rich in the towns of Makale and Rantepao. By 1996, there were about 1,300 telephone connections in Makale and 3,100 in Rantepao. Providing exclusive access to telephones only for people in Makale and Rantepao has unintentionally led to a brokering role for some people in the transfer of information. This broker role becomes very clear in the interview with Pong Pedi:

Because I live in Rantepao and possess a telephone and fax machine in my house, all communications between my family in Makassar, Java and Kalimantan, and my family in the mountain villages pass through my house. I do not have to go to the villages in person to pass on the information because I can give the information to the pete pete (minibus) driver who drives up to the villages every day. The driver will convey the news to the villagers, and the other way around it works in the same way. The driver passes on the information without charging any money or expecting anything in return. However, when I want to go to a village, I am more-or-less obliged to go with that particular driver.

In the introduction to this book it was already noted how tante also fulfilled a form of brokers-role in the family house in Makale through informing migrant family members about forthcoming ceremonies and unexpected events while, at the same time, passing information about migrants on to relatives in Tana Toraja. Moreover, we saw that this communication system works quite well, with guests attending ceremonies without official invitations from the organizers, and rarely does anyone miss a ceremony in honor of even the most distant acquaintance.

Although wireless telephones have recently been introduced into the highlands, hand phones can only be used within a radius of twenty kilometres around Rantepao and Makale. In the remote village of Baruppu, which is about a three-hour drive from Rantepao in the dry season, a migrant working for an American company in Balikpapan, Kalimantan, had installed two satellite telephones that connected the inhabitants with the wider world (as far as Malaysia). This was seen as quite an improvement by many people because it was much cheaper than going to Rantepao. Travelling to Rantepao by petepete (minbus) costs about Rp 15.00o. In addition, passengers generally have to eat and spend the night there before they can return the next day. However, the generator that is needed to get any signal has broken down and the villagers again need to go down to Rantepao. 
Students from Baruppu who study in Rantepao also deliver messages. They usually return to Baruppu on the Saturday and go back to Rantepao after Sunday Mass. On other occasions, messages are delivered through petepete drivers. Notwithstanding the important role that some people in Makale and Rantepao currently fill in communicating information to migrants and those in the villages, this role is slowly decreasing. People with a cell phone living within reach of the antennas in Makale and Rantepao are already replacing the brokers' role. In the village of Palipu', for example, most communication with migrants now runs through the cell phone of Pa'Marrung. Pa'Marrung is a wealthy man, and his cell phone was sent by his son who is working in South Korea. Whenever Kristina wants to contact her parents, she phones Pa'Marrung. However, she prefers to contact him at his office in Makale because this is much cheaper than through his cell phone.

In Kondo', it is not very different, Lucie can communicate by phone with her younger brother who is working at a highschool in the neighbouring village of Tondon Batuk. After I made an appointment for an interview with Rosmina in Makassar, she contacted her family in Tana Toraja to find out about me. She did this through phoning the neighbours of her family who own a cell phone. As of 2005, Tana Toraja still lacked an internet provider and using any web-based communication was, for the vast majority, still out of the question. ${ }^{28}$ However, fax, telephone and road improvements have made communication much quicker, increasing the influence of people in Makassar on household decisions in Tana Toraja, and also vice versa. In particular, migrants of high class families often call home for information about forthcoming ceremonies or to meddle in the organization of important ceremonies. Torajan families in the highlands, conversely, often call their migrant relatives for financial contributions or advice on buying pigs or buffalo for a particular ceremony.

\section{The Homecoming Myth: Metaphor or Reality?}

Torajan migrants say that they are longing for their homeland and, even if they have already been living elsewhere for several decades, that their mind is still with their family in Tana Toraja. The majority wish to return to the highlands permanently, even if this is not a realistic option. Thus, the identity of Torajans in Makassar as a group and as individuals is

28 It is worth emphasizing that, in contrast to Tana Toraja, communication through the Internet among Torajans in the various diasporas has been rapidly increasing. 
inextricably related to their identification with Tana Toraja, and as such Makassar has become a metaphor for Tana Toraja. However, this metaphor seems a little too metaphorical as the homecoming myth does not really appeal to most people. People from the lowest classes are not actually longing to go back to their dependent and outcast position in Tana Toraja, and the poor are not eager to show their disappointing failure to make a fortune in the city to relatives in the homeland. Torajan organizations are generally headed by high-class elders or wealthy people from the middle class. These are the people trying hardest to sustain the Torajan world. However, the Torajan world is not a harmonious whole, and there are some lines of fracture running right through it, especially as it concerns the less fortunate people. Further, for the second- and third- generation Torajan migrants it is not very obvious that they feel Torajan, and there are also people who feel somewhere in between. The latter have mixed feelings about their ethnic identity. This continuing dilemma of feeling in-between was very well illustrated in an interview with Juliet, who is one of 250 students at the Theological College in Makassar. She is 22 years old with a Torajan father and a mother from Manado. When I asked her about her identity, she somewhat confusedly started a monologue about her struggle in living between 'we and them':

The people in Tana Toraja know me well, but I do not know them. Like last year, when I went to a funeral ceremony, everybody seemed to know me. My relations with Torajans are not very close. Honestly, I feel Makassar, and I am more Makassar than Torajan. I was born in this culture and grew up here. Torajan people are hard. They spend their money on things which are not very useful. For example, on this campus, they usually buy ballo', which is a traditional palm wine from Tana Toraja. They drink it to remember their culture and homeland. The Torajan students impose their ideas upon other students. In a positive sense, Torajan students are very close to each other. Because they are very far from their village, they try to be as one in this place and care a lot about each other, whether they are acting right or wrong. The situation in the dormitory is such that they never meet with people from other ethnic groups such as the Bataks or people from Kupang [Timor]. They use their own language which makes it very difficult for 'outsiders' to join in. They create a gap surrounding 'them and themselves' by using their language. In the night they sleep together like roommates, but in daily life they live separately. It is very difficult to integrate, but the same is true with other ethnic groups who use their own language. Because of the Torajan attitude, the situation is similar at other universities in Makassar; they all stick together to make themselves feel satisfied. When the Torajan students at this campus have a problem, they gather at the house of the 'parents'. This Torajan couple is living and teaching on the Campus. In the Torajan language, they have the phrase "Misa' kada, potuo pantan kada di pomate", 
which means that, everywhere you are, you must remember that you are from the same mother. Torajans always use this phrase. When we met at the parents' house, we first started with these words. Yes, we always have to remember this! That is when I think that I am a full Torajan from Makassar. You can call this phrase a binding element for Torajans, because everywhere they go they use it. Not only in Makassar but everywhere they are.

In my family they still have a Torajan attitude, especially my uncle. He is often going to Tana Toraja for funeral ceremonies. We spend a lot of money on funeral ceremonies. My father also spends a lot of money when he is there [in Tana Toraja]. He does not care about money when he is in Tana Toraja but when he is back in Makassar he feels sorry again. Our family always thinks back after he returns to Makassar. We feel very sad about wasting so much money on funerals but we have to. We always think about our debts [through the funeral system]. We have a lot of debts in Tana Toraja and that is why my father often goes up there. It gives me a headache and I am afraid to go to Tana Toraja. When I go there I must face my debts. My father always tells me 'when there is a funeral of relatives which are not too close, please do not attend it or we will get more debts'. I have to say that I am an only child, and this makes the weight of these debts even heavier. My parents have lived in Makassar already for 20-30 years. They made me Makasar. They know all about the good things in Tana Toraja but they warn me about the Torajan attitude. They tell me 'please do not get involved too much in their traditions, especially the funeral ceremonies'.

From this assessment, I would like to draw some insights for further discussion. First, concerning the way in which Torajan students in Makassar use visible ethnic strength to develop group confidence and a sense of security, resulting in 'spaces of difference' as Laguerre (2000:155) calls it. The Torajan language (including phrases), family names, descent and cultural norms (defining status and behaviour) all form elements that keep Torajans together as a group in an alien environment. Moreover, the bargaining position of Torajans in interactions with other Torajans in Makassar is defined by their position in the homeland. In other words, the Torajan transmigrant community in Makassar more-or-less mirrors Torajan society in the highlands. Alongside the binding elements discussed above, the Torajan iconographic system has become a powerful symbol of their identity; declaring that 'the mountain people once considered to be of little consequence are now nationally and internationally recognized' (Morrell 2001:22). The signs on Torajan houses or tongkonan pop up everywhere in Makassar. Hotel entrances or even complete buildings are topped with a typical Torajan-style roof. A prominent hotel complex along the boulevard in Makassar consists of buildings that are designed as tongkonan. Tongkonan elements, and especially the façades' 
designs, are attached to Indonesian-style houses, and heaps of miniature tongkonan, t-shirts printed with tongkonan, and keyrings in the shape of a tongkonan, are sold in the souvenir shops of Makassar. Moreover, artefacts or handicrafts with Torajan designs are displayed in the guest rooms of the better-off Torajans, and also of Bugis, Makasar and Mandar alike. Because of international and domestic promotion of tourism by the Indonesian government, 'posters, magazines, newspaper articles and television films publicize the architecture and rituals, creating greater awareness of Torajan identity within, and outside of, Tana Toraja' (Morrell 2001:22). This commodification of ritual and material culture has certainly contributed to the strengthening of the Torajan identity in and beyond Makassar.

The second point I want to pick up on from the interview with Juliet is the issue of being torn between two places, Tana Toraja and Makassar. Often Torajans act as if they were forced to migrate (as part of a diaspora) and, as a result, they are always longing for 'home'. Most of their activities in Makassar are related to objectives in Tana Toraja, such as a future funeral, house-building or eventual retirement in the highlands. Many wealthy Torajans still have a house in Tana Toraja in case they want to return in the future. All the first generation migrants I spoke with indicated they had plans to return to Tana Toraja in the future, when they are retired or when their children finish their education and become financially independent. These people are making a living in Makassar but they are not actually living there.

For the Torajans born in Makassar (second- and third- generation migrants) it is a little more complicated. They usually face problems similar to those of people with mixed-ethnic parents or Torajans within interethnic marriages. This is the third and last issue which I want to draw on. The people within these groups are not so much torn between two places as between two ethnic groups; both with their own cultural repertoire and in terms of accompanying obligations. In the event of inter-ethnic marriages, all the couples that I talked to (both the men and the women) married in Tana Toraja. A Muslim from the city of Manado (in the northern part of Sulawesi) was very impressed by the thousands of people who turned up for his wedding ceremony in a village in Tana Toraja. His Torajan wife, who originates from a high-class family, was quick to add that all visitors were family. After marriage, the man became a Christian, which is also not unusual. Although the Torajan culture is usually a little more dominant in inter-ethnic marriages-probably through the demanding funeral ceremonies and the debt system that comes with it, most Torajans in these relationships are balancing between two cultures. Like children of 
a couple with one Torajan parent, their identity depends on the occasion and the place they are at currently. Most second- and third-generation Torajan migrants become increasingly translocal. While they are born in Makassar, they might easily work elsewhere in Indonesia. They still return to the highlands for funeral ceremonies, but they do not always feel Torajan. As Michel, who was born in Makassar but is now living in EastKalimantan, explained 'I grew up as a migrant and used to move around, I have been living in different places and among various ethnic groups. I have Torajan parents but feel more Indonesian than Torajan.' To summarize, there remains a distinction between Torajan-ness and Indonesianness that Torajan migrants have to manage. While the majority have no problems in bridging this distinction, some are living in two worlds, or even opt solely for the Indonesian world, especially those who are thirdgeneration migrants.

\section{Conclusions}

In this chapter I gave a more detailed view on the way Tana Toraja changed and in some ways new perspectives on Toraja outmigration by compiling existing literature on this topic and coming up with new data from interviews and archives. This chapter has made clear how the Torajan world has quickly become a transnational social space that includes many places in Indonesia, Malaysia, Hong Kong and elsewhere. Especially 'after merantau', many Torajans have left the highlands in search of money or to pursue higher education. Now, the number of Torajans living outside the highlands far exceeds the population in the heartland, and the Torajan world is ever growing. Together with conflicts and decentralization, the increasing scale of the Torajan migrant world has led to the development of an allembracing Torajan organization. Many types of Torajan networks and organizations are rapidly emerging in regions with high concentrations of Torajan migrants.

The Torajan world thus includes Torajan migrant networks that cross local boundaries and are in that sense translocal or even transnational. These networks are bound together through collective memories and images (and their exchanges) of a common place of origin. However, unlike many other transnational networks that become detached from any particular place and in that sense can be considered as 'imagined communities', the Torajan transmigrant network stays firmly anchored to the place of origin and is, in that sense, 'imagined, but not imaginary' 
(Jenkins 2002). Torajan migrants maintain strong ties with their family and acquaintances in the highlands (especially through participating in ritual performances), including those migrants from the second and third generations who were not born in Tana Toraja. In reality, the wealth, power and status of migrant Torajans in the diaspora is inextricably linked to the heartland and would not even exist without these relations.

Makassar is an important node in the Torajan world, where people maintain both forward as well as backward relations with other Torajans. To some extent it has become a kind of economic extension of Tana Toraja, through providing a new field for work and income. Further, in Makassar, the Torajan world is reconstructed and reproduced, and new cultural models are developed of Tana Toraja that come close to what already exists in the homeland. To some extent, Makassar has become more Torajan than Tana Toraja itself, reflected in the social organization, iconographic system, artefacts, etc. In Makassar, Tana Toraja is often pictured in an ideal romanticized way.

However, even though Makassar is an important center from which elites influence and design politics and policy for Tana Toraja, and where the cultural and symbolic world is (re)invented, the nodes of influence in Tana Toraja itself are still relevant. We need to study particular nodes of the Torajan world in Tana Toraja because the Torajan diaspora in Makassar would not exist without the heartland. Moreover, while the Torajan diaspora in Makassar influences the people and the way they make a living, in Tana Toraja, Torajans remaining in the highlands influence their migrantrelatives in Makassar. The two exemplary cases elaborated in this study depicted the Torajan world from that other perspective, namely, from the heartland. 